\title{
Gamification in Management Education: A Systematic Literature Review
}

Received 6 September 2018. This paper was with the authors for three revisions. Accepted 29 May 2019. First published online 28 June 2019.

Rodrigo Baroni de Carvalho was the associate editor for this article.

Editorial assistant: Luciane Kato Kiwara

Editor-in-chief: Carlo Gabriel Porto Bellini 


\begin{abstract}
Quality of teaching is increasingly important for the success of educational institutions. In this context, gamification is a tool often used to improve the teaching-learning process by helping both teachers and students reach their goals in the short, medium and long term. Given the importance of the topic both in academia and society, this article presents a systematic review of the literature on the use of gamification as a tool to enhance the quality of the teaching process in general, and, in particular, the teaching of management. The study searches the most relevant literature on the application of gamification to educational contexts and describes gamification's main themes and constructs based on a systematic literature review of scholarly articles available in ISI Web of Science and Scopus databases. One of the main results of this study is to describe theoretical approaches to gamification and provide a conceptual model that gathers the contribution of various studies and paves the way for future research.
\end{abstract}

Keywords: gamification; game-based learning; education; management. 


\section{Introduction}

Like any organization that wants to improve the quality of its services and products, educational institutions have the responsibility to ensure that their students get quality education at all levels (Yildiz, 2014). Educational institutions as well as instructors are expected to fulfill their obligations with the utmost quality so that future generations can be well prepared to go into the labor market (Hill, 1995). It is generally accepted that the quality of teaching is essential for the success of an institution and of its students; therefore, it is important to assess and monitor the quality of teachers' work (C.-Y. Chen, Chen, \& Chen, 2014). Experts on education and, more specifically, on the quality of education, have been working hard to improve the quality of the teaching-learning process at all levels and in various aspects of the curriculum (Langstrand, Cronemyr, \& Poksinska, 2015).

It is vital that teachers motivate their students, making them aware of the fact that what seems difficult is not always necessarily so. At the same time, instructors have to know that traditionally established methods are not always the ones that attract students the most. In fact, although many instructors favor the use of innovative methodologies, there is a broad and empirically verified consensus that student motivation and interest for traditional teaching methods are scant because they are deemed ineffective (Lee \& Hammer, 2011).

The use of educational games as learning tools constitutes an approach that can strengthen not only student knowledge but also their ability to communicate and cooperate with schoolmates in what concerns the understanding of learning content (Hamari, Koivisto, \& Sarsa, 2014). The use of games in the classroom may help students acquire new study methods, making them feel more motivated than when they are exposed to more traditional teaching-learning processes (Kapp, 2012b). Yet, only recently have instructors begun to explore the possibility of turning the classroom into a place where educational games are not only possible but also feasible, effective and academically enticing (Glover, 2013).

Although several studies have tested gamification in general, and, in particular, the use of educational games in the classroom, from primary education to higher education (Deterding, 2012; Hamari et al., 2014; Hamari \& Koivisto, 2015), more empirical studies are necessary to actually demonstrate the effectiveness of such approach. Studies should be based on well-designed methodologies, robust comparison groups, longitudinal treatments and empirically validated assessments (Hamari et al., 2014). In the field of management, studies that show how game-based learning may have a positive influence in education are still scarce. Moreover, despite its motivating power in making students get involved, gamification faces serious problems that have to do with designing and applying games to teaching (Conway, 2014). As a matter of fact, it is both difficult and expensive to use games in the classroom, since it implies having suitable technical infrastructures and pedagogic integration at one's disposal.

This article presents a number of results about game-based learning in order to highlight more adequate and effective trends and practices. As this is a recently developed subject, there is still the possibility to expand already available knowledge through literature reviews (Hamari et al.,

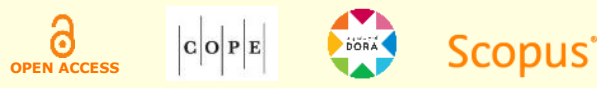


2014; Martí-Parreño, Méndez-Ibáñez, \& Alonso-Arroyo, 2016; Nah, Zeng, Telaprolu, Ayyappa, \& Eschenbrenner, 2014; Surendeleg, Murwa, Yun, \& Kim, 2014). The main goal of this article is to develop a conceptual research model of applying games to management education based on a systematic literature review that focuses on the most relevant literature regarding the application of gamification to educational contexts in order to grasp gamification's main themes and constructs.

As the use of games in the teaching-learning process is a promising tool to effectively motivate students and get them involved, and as most of the research conducted so far has failed to provide a compelling literature review on the subject and a conceptual research model, the present article may help researchers have a better understanding of how research pertaining to this field has been evolving. The analysis herein made it possible to identify and show how games are used in an educational context, as well as what their contribution is to increase motivation, flow, and attitude, besides proving its effectiveness in terms of the learning process. The scholarly literature on the use of games in the teaching-learning process was organized, and the most relevant constructs were identified along with how they relate to and interact with each other, thus allowing future research to use this study as a starting point.

The present article contributes to the advancement of the literature about the application of gamification to the teaching of the various areas of Management. We did a systematic review of the literature based on rigorous criteria presented in the methodology section, followed by a review of the literature of the main topics in this area, such as gamification in general, gamification applied to general education and in teaching of Management. There is also a section addressing the main constructs of gamification. We conclude that motivation, flow, attitudes and perceived learning are the most relevant constructs, and we verify the type of causal relations between them. Finally, we discuss the conceptual research model resulting from the literature review.

\section{Research Methodology}

Research applied to game-based learning in management education is a very interesting area that motivated systematic literature reviews (e.g., Connolly, Boyle, MacArthur, Hainey, \& Boyle, 2012; Darejeh \& Salim, 2016; Johnson et al., 2016; Sardi, Idri, \& Fernández-Alemán, 2017). Thus, the present study and the methodology underlying it are based in other studies that ensured systematizing the literature (Armitage, Webb, \& Glynn, 2016; Kitchenham et al., 2009; Patel et al., 2008; Tranfield, Denyer, \& Smart, 2003). Only articles in journals indexed by ISI Web of Science (WOS) and SCOPUS databases were used, since they are the most acknowledged and used for such purposes (Podsakoff, Mackenzie, Bachrach, \& Podsakoff, 2005).

Data gathering took place in December 2017, without any chronological filter, and it resorted to Web of Science TM Core Collection (WOS) and Scopus (SCO) databases. The keywords used for the three separate searches were Gamification, Gamification and Education, Gamification and Management. The reason was to gather as many articles as possible on the field and sub-areas of management, making sure the articles that were selected covered the topic as extensively as possible. The outputs were successively filtered, until we had only peer-reviewed articles. Books, proceedings and non-scholarly documents were excluded.
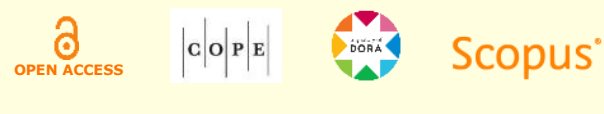
In terms of areas covered by the databases, they are organized in different ways, with WOS having Management, Economics and Business, and SCO having two large groups: Economics, Econometrics and Finance, and Business, Management and Accounting. In the first methodological stage, the present study focused on gamification in general (Gamification), crossreferencing it with game-based learning (Gamification and Education) and management (Gamification and Management). The result were 565 articles in WOS and 701 in SCO. The outputs of the two databases were then cross-referenced, and duplicates were excluded, resulting in 841 articles. Then, the following inclusion criteria were established: (a) articles on game-based learning, and (b) review articles and literature roadmaps on the use of gamification. After perusing abstracts and/or complete articles, 597 of the latter were excluded and 244 included. The 244 articles that were selected in WOS and SCOPUS were published between 2012 and 2017. We then proceed to content analysis in three stages.

In the first stage, all abstracts, literature review, and final considerations were read and a document was created to contain the most relevant information extracted from those sections of each article. Subsequently, a chart was developed to present all subjects approached and the main conclusions (Beelmann, 2006). Finally, the contents were divided according to the main constructs in order to create a text that could provide an explanation of the main theoretical approaches for each subject related to gamification applied to the teaching-learning process, and the conclusions that had been drawn. Figure 1 presents the research layout that led to the final set of articles.

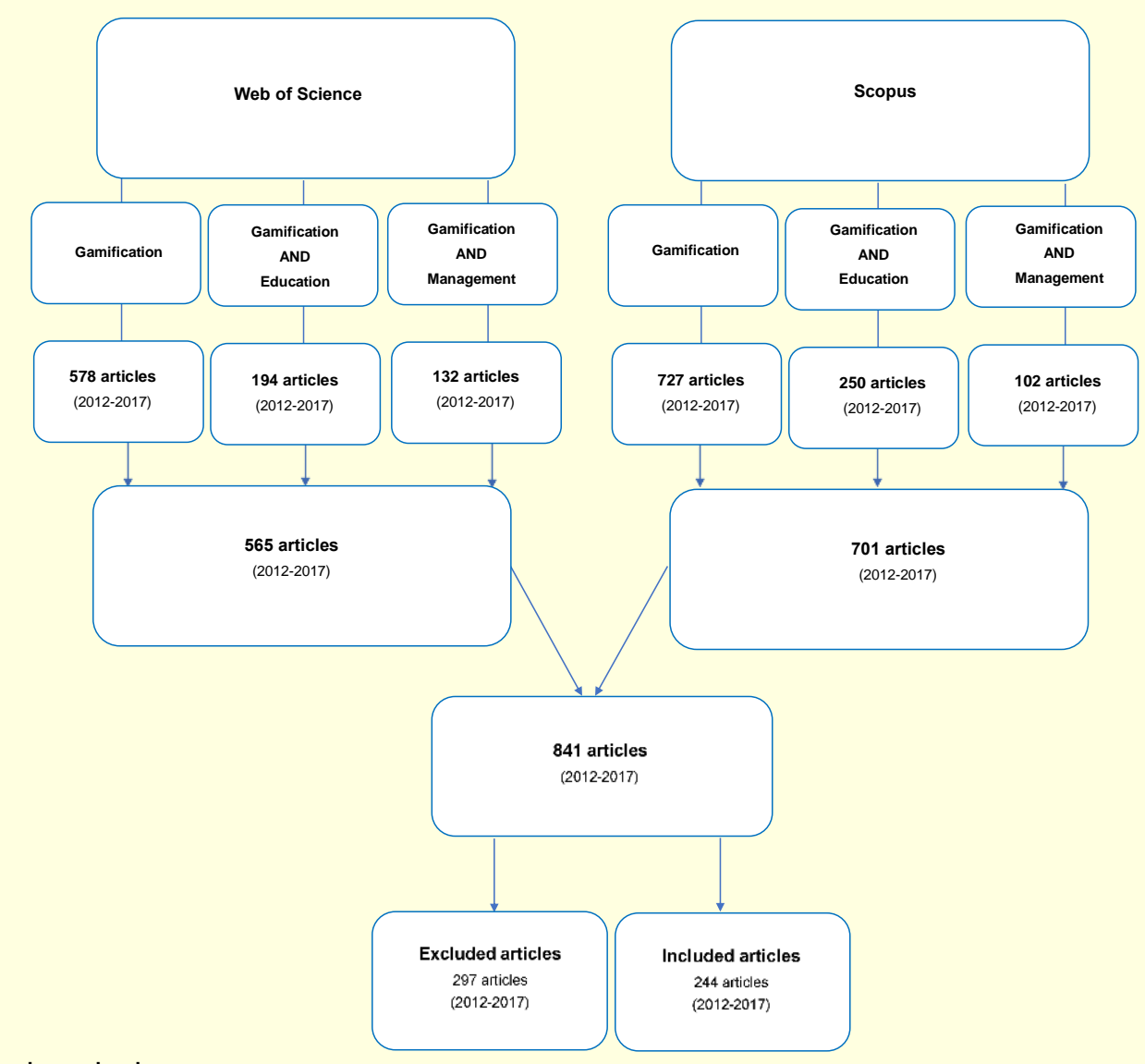

Figure 1. Review design 


\section{Systematic Literature Review}

\section{Gamification}

Since 2010, gamification has arisen to increase an individual's involvement, motivation and attitude by using games in non-game contexts (Deterding, Sicart, Nacke, O'Hara, \& Dixon, 2011). Gamification was first used in marketing and later implemented in other areas like health (Schoech, Boyas, Black, \& Elias-Lambert, 2013), environment (Filsecker \& Hickey, 2014), sports (Koivisto \& Hamari, 2014), engineering (Huotari \& Hamari, 2017), mathematics (Attali \& ArieliAttali, 2015), computer science (Domínguez et al., 2013), biology (Su \& Cheng, 2015), communication (Hanus \& Fox, 2015), and psychology (Landers \& Landers, 2014). Gamification is typically described as the use of elements of game design in non-game contexts (Deterding, Dixon, Khaled, \& Nacke, 2011; Koivisto \& Hamari, 2014; Werbach \& Hunter, 2012). Still, research must continue to happen on the theoretical bases, broader goals and more consistent empirical practices on the subject (Deterding, Dixon, et al., 2011), as well as on the impact of application on other areas (Zichermann \& Cunningham, 2011).

The aim of gamification is to support and motivate users to perform a given task (Deterding, Sicart, et al., 2011; Domínguez et al., 2013; Huotari \& Hamari, 2012), engaging them in the activities (Csikszentmihalyi, 1990; Deci \& Ryan, 1985; Deterding, Sicart, et al., 2011; Hamari, 2013; Ryan, Rigby, \& Przybylski, 2006), and to foster their interest in a certain area that may enhance learning (Huotari \& Hamari, 2012). In an educational context, gamification has a great potential to motivate students, making the school environment more attractive (Lee \& Hammer, 2011), since it is a process aimed at improving educational activities (Gibson, Ostashewski, Flintoff, Grant, \& Knight, 2015; Lee \& Hammer, 2011; Werbach \& Hunter, 2012). As such, the idea that game-based learning only involves playing makes is a limited one; learning should not be a dull experience, but a motivating and pleasant one (Wu, 2011). Several authors agree on the benefits of gamification to a target audience (Stott \& Neustaedter, 2013), because games allow users to err and try again, facing learning without fear, and consequently becoming more involved in the learning process (Lee \& Hammer, 2011).

The feedback students get from their teachers is very important to help them progress and move to the next level (Kapp, 2012a), thus mastering due contents. Gamification promotes student motivation and engagement (Clark \& Rossiter, 2008), as well as interest and improvement (Camilleri, Busuttil, \& Montebello, 2011; Kapp, 2012a). It is possible to say that the number of people who use a certain game-based resource may have a positive impact on the users' motivation, who are more likely to continue using it (Lin \& Bhattacherjee, 2008). In general, findings on the impact of gamification take on several forms that can be positive, negative, mixed or even null. This is due to gamification not influencing all participants alike. Nevertheless, it has been considered beneficial by several authors (Brunsell \& Horejsi, 2011; González \& Area, 2013; Hellwege \& Robertson, 2012; McGonigal, 2011; Muntean, 2011). 
When one looks into the studies that are most frequently cited in the literature, it is possible, according to Domínguez et al. (2013), to find examples of motivation increase, at an early stage, but also of bad performance, as well as of an increase of interest shown by users of a marketing game (Downes-Le Guin, Baker, Mechling, \& Ruyle, 2012), or the various effects of using gamebased resources (Gäsland,2011; Witt, 2011). Other studies have drawn attention to the fact that there are demographic differences regarding gamification impacts and effectiveness. Bagley (2012) concluded that age and familiarity with games increase users' interest in such resources, while McDaniel and Fanfarelli (2016) claim there is no gender-related difference in the impact of gamification. Demographic differences are relevant indeed when one looks into the use of game-based technology (Venkatesh, Morris, \& Ackerman, 2000), as some of the differences regarding perception and motivation to use technology have shown that the intent to use may change, or not, according to demographic factors (Venkatesh et al., 2000). Researchers have not paid much attention to age and gender as variables that may influence the use of such resources as games, but they may account for differences in the use and motivation to use (Greenberg, Sherry, Lachlan, Lucas, \& Holmstrom, 2010; Griffiths, Davies, \& Chappell, 2003; Williams, Yee, $\&$ Caplan, 2008). Other studies have shown that feedback on progress has improved learning and has reduced failure rates (Bellotti et al., 2013).

Charles, Charles, McNeill, Bustard, and Black (2011) applied gamification to an entrepreneurship course, using incentives that were proportional to each player's success. It allowed students to get a better learning and achieve higher levels of motivation, although they participated less in classes that followed a traditional model. Hamari and Koivisto (2014) concluded that gamification involves an aspect of novelty that tends to wear off over time. And, according to Deci, Koestner and Ryan (2001), rewarding the effort and success, as it happens with games, increases motivation; on the other hand, others think that performing a task that is in itself interesting and being rewarded for it may hinder motivation (Lepper, Greene, \& Nisbett, 1973; Ryan \& Deci, 2000a). Also, gamification in the classroom helps increase intrinsic motivation (McGonigal, 2011), thus it should be used and promoted. However, the use of rewards, which usually recognize one's skills and knowledge, does not always motivate students (Abramovich, Schunn, \& Higashi, 2013; Hickey \& Rehak, 2013; Landers \& Callan, 2011; Muntean, 2011).

Hamari, Koivisto and Sarsa (2014) think there are not enough studies that provide information on the differences between using gamification and not using it (such as in a control group), so that it is possible to understand what happens within each group. Although the applications of gamification are promising, there is the need for more empirical evidence of its usefulness and ability to increase the interest of those who use it in an educational context. Gamification is then a concept that is still being developed and one that shows there is room for improvement concerning its real effects (Kapp, 2012a).

\section{Gamification in education}

Over the years, there have been attempts to apply game-based learning to education in order to stimulate students to behave well towards education (Denny, 2013). The goal is to make students
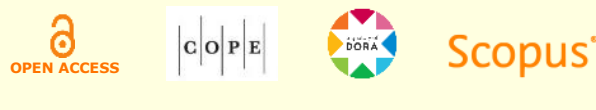
participate in all activities that have to do with the various learning areas, encouraging them to use teaching aids that appeal to them (Denny, 2013; Domínguez et al., 2013; Moccozet, Tardy, Opprecht, \& Léonard, 2013; Simões, Redondo, \& Vilas, 2013).

The game-based structures that have been applied to education resort to badges and rewards to recognize student improvement based on a classification system that assesses the skills and levels of knowledge evidenced by players during the game. The classification system uses competitiveness as the force behind the game's dynamics in the form of charts and ranking lists that rank students in ascending order (C. Li, Dong, Untch, \& Chasteen, 2013). Although rewards promote competitiveness, interest and motivation among students, the rivalry they are likely to cause can also produce negative results (Zichermann \& Cunningham, 2011). That is why gamebased education has to deal with some important challenges, of which the most important one is to get students accept this kind of learning environment before it can be said to be successful. Therefore, the goals, the type of feedback and the rewards must be clearly defined, keeping the students immersed in a flow of positive and individually involving learning (Csikszentmihalyi, 1990). This is essential if students are to be always kept engaged and informed of the progress they have made and that has contributed to their satisfaction and academic achievement (Trowler, 2010).

For Kahu (2013), student engagement in activities may be divided into three major components, called behavioral, cognitive, and affective. Behavioral involvement is the positive behavior shown by students who take part in learning activities demonstrating effort, persistence and attention and no sign of a negative, deviant behavior (Finn, Pannozzo, \& Voelkl, 1995). Cognitive involvement refers to students' investment in mastering a certain subject (Fredricks, Blumenfeld, \& Paris, 2004).

As for affective involvement, it has to do with students' willingness to perform the tasks that have been assigned to them, showing their interest through positive attitudes (Appleton, Christenson, \& Furlong, 2008). It is possible to use game-based resources in a formal or informal school context, provided that there is some level of involvement for, according to Denny (2013), this type of resources contributing to raising participation in learning activities.

Many authors have created and tested tools in an educational context. Domínguez et al. (2013) created a game-based service that rewarded the best players by giving them badges and prizes, according to their ranking in the classification charts. This idea, however, caused some discomfort among the students. Unlike what happened with a group of college students during an electromechanics class, the students who used game-based resources behaved in a more confident way and were prouder to publicly show their achievements than those who chose not to use them (Foster, Sheridan, Irish, \& Frost, 2012). But one should bear in mind that students need their instructor' help to feel motivated in the classroom (extrinsic motivation), and that prizes and rewards are but a way to stimulate the competitive spirit among students (McDaniel, Lindgren, \& Friskics, 2012). 
Another teaching aid based on the principles of gamification designed to help students prepare for finals was considered useful and easy to use. However, the game-based elements did not reach the intended goals due to the nature of the task (studying), the way the task was presented to the students (without any prospect of fun), and the fact that the aims of using such tool were not properly explained (Gåsland, 2011). Goehle (2013) created an electronic application that included several game-based elements, whose purpose was to assist home teaching. In spite of students believing that the system made them feel more appreciated for their effort, it was not possible to prove how using the tool impacted their performance. W. Li, Grossman and Fitzmaurice (2012) developed a tutorial system to help students access AutoCAD using several strategies like assignments, scoring (both numerical and visual through stars), various game levels, time pressure for problem-solving and rewards or bonuses. The authors were able to ascertain the strategy has increased the students' engagement, entertainment and performance.

According to Klopfer, Osterweil and Salen (2009), all educational games should rely on certain mechanics and dynamics. Game mechanics are constructs of rules and rewards, whereas dynamics consists of the wishes and emotions the game awakens in the players. Some authors (e.g., Lee $\&$ Hammer, 2011; Linehan, Kirman, Lawson, \& Chan, 2011) have drawn attention to a number of rules that must necessarily be part of a game: allowing the repetition of experiences so that a goal may be attained, including immediate feedback on performance during the game, allowing different opportunities for success, and awarding good performance.

It is critical that one realizes the importance of using games in an educational context, but bearing in mind that it must satisfy both students and instructors. The use of games should give instructors the opportunity to create challenges that are suitable for the students' level of knowledge, raising the level of difficulty as new skills are acquired (Kuh, Kinzie, Schuh, \& Whitt, 2011); create new ways to enable students to reach intermediary goals during the learning process (Biggs, 1999); provide students with feedback on learning by designing new tasks with higher levels of difficulty (Huang \& Soman, 2013); use failure as part of learning; use the trial-and-error method for the successful completion of tasks, and not resorting to penalties (Hattie \& Timperley, 2007); allow students to take on new identities and play different roles that let them explore different aspects of their personality (Banks, 2008); and use competitiveness among students as a means to promote learning (Schuler \& Jackson, 1987).

As previously stated, education and learning have been the stage of many gamification experiences, and some positive results stemming from the application of game-based strategies have been identified, concerning the students' interest and motivation. In fact, authors like Hamari et al. (2014) claim learning and flow are guaranteed in such cases, although they also recognize the need for more studies regarding effective learning in various fields of knowledge. It is clear that the mere use of game-based mechanisms, no matter the area of expertise, does not assure that learning goals will be achieved (Dicheva, Dichev, Agre, \& Angelova, 2015). 


\section{Gamification in management education}

Monopoly was the first board game used in higher education in the area of Management. It soon became popular to play it at home as a cooperative game (Whitehill, 1999). In the mid-1950s, under the influence of what happened during World War II and the appearance of mainframe computers, the American Management Association came up with a simulation called Top Management (Cohen \& Rhenman, 1961), followed by a game whose purpose was to become a backup tool for a Business Studies and Politics course (Albrecht, 1995). By that time, many were the management decision games being used at the universities of Michigan, California, Pennsylvania and Indiana (Cohen \& Rhenman, 1961). Several adaptations of the games emerged focusing on decision-making in specific business areas, such as Operations Research, General Administration, Marketing Strategies, and Management Accounting.

In Accounting, several concepts were approached, and instructors were encouraged to use creative methodologies and adopt technology-based teaching (Fratto, 2012). Several adaptations of Monopoly were then made available (M. M. Tanner \& Lindquist, 1998), and spreadsheets and word processors were used to create quiz-type games (Moncada \& Moncada, 2014). Game-based activities, focusing on improving learning in Financing Accounting courses became usual, adapting other games and turning them into tools that, in spite of having not been specifically designed for teaching Management in general and, in particular, Accounting, they were nevertheless effective. Adaptations of Jeopardy (Cook, 1997) with the help of PowerPoint (Murphy, 2005) and Excel (Bee \& Hayes, 2011) led to the creation of teaching aids that, even if being quite simple, helped improve practices and revise concepts in accounting (Moncada \& Moncada, 2014). More recently, several game-based resources have been applied to various other areas of Management (Avramenko, 2012; Ceschi, Dorofeeva, \& Sartori, 2014; Dias, 2017; FitóBertran, Hernández-Lara, \& Serradell-López, 2014), such as Marketing (J. R. Tanner, Stewart, Totaro, \& Hargrave, 2012), Entrepreneurship (Antonaci et al., 2015; Arias Aranda, Bustinza Sanchez, \& Djundubaev, 2016), Industrial Production (Müller, Reise, \& Seliger, 2015), Tourism (Adukaite, Zyl, Er, \& Cantoni, 2017; F. Xu, Buhalis, \& Weber, 2017), Innovation (Yalabik, Howard, \& Roden, 2012) and General Administration (Kumari, 2019).

Also, several authors have tested different business simulation platforms in trying to see how they influence learning in Management and Accounting. They concluded that the business simulations were instrumental in preparing Accounting students to manage a business, helping them be prepared to take on the role of future business leaders and refining their decision-making skills (Carenys, Moya, \& Perramon, 2017; Riley, Cadotte, Bonney, \& MacGuire, 2013).

Yet, there are also studies that point to the opposite conclusion as regards this type of educational resource, highlighting that, in Accounting, they do not improve learning (Krom, 2012; Tao, Cheng, \& Sun, 2009), and stressing the need for more research that can test their usefulness beyond doubt (Carenys et al., 2017). We also mention studies on Management education, where the application of gamification is very rare and still lacks significant empirical evidence (Moncada $\&$ Moncada, 2014). As regards the application of gamification to Management, there is scarcity of scholarly studies and lack in both robust conclusions and scope, resulting only from very

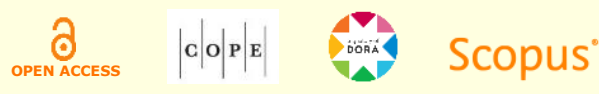


limited studies. Also, there is scarcity of tools suitable to making broader and more effective approaches. After the present literature review of gamification in Management education, we confirm that such studies remain rare (Dichev \& Dicheva, 2017). We also verify that, contrary to the other previously mentioned fields, there is still a long path to follow in Management as regards the scientific evidence resulting from applying gamification (Dale, 2014).

\section{Gamification Constructs}

Gamification includes constructs that explain how one can apply gamification tools to educational interests, while promoting motivation, attitudes, flow, and learning. Several theories have been used in gamification studies, namely Landers' theory of gamified learning (2014), Ryan's and Deci's self-determination theory (SDT) (2000b), Csikszentmihalyi's (1990) flow theory and Ajzen's (1991) theory of planned behavior; the aim is to try and to understand how motivation (MOT), flow (FLO) and attitudes (ATT), which emerged in the application of gamebased resources to the teaching of Management, can influence perceived learning (PLE).

\section{Motivation}

Most studies that have been looked into in this literature review focused on the impact of gamification, in general, and, in particular, on the influence of games-based learning (GBL) on the teaching-learning process. In all studies, the common denominator is the application of a game to an area of knowledge with the purpose of understanding its motivational impacts on flow, attitudes and perceived learning. The research goals regarding the use of gamification are clear: verifying a game's impact on students' motivation, analyzing students' knowledge flow after becoming familiar with the game-based resource, studying the students' attitude to continue using the resource after having used it for the first time, and knowing the impacts on perceived learning of using this type of resource (Hamari et al., 2014).

Motivation is a construct used to explain the direction, intensity, persistence and quality of a given human behavior (Maehr \& Meyer, 1997). In the literature, it is described as varying in magnitude and orientation. Motivation, whether intrinsic or extrinsic, is used as a mediating variable that accounts for several types of behavior in different contexts and environments (Ryan $\&$ Deci, 2000a). In education, it is considered a key element in learning and used to explain the effort and attention invested by students in activities in which they are involved (Brophy, 2013). In this context, it is up to the instructors to manage student motivation and raising it when possible, so that the learning process has positive results (Harlen \& Crick, 2003).

\section{Flow}

Educational games are developed to educate and train, integrating serious work elements into a game context, what may make emerge the state of flow (Csikszentmihalyi, 1990). Flow is a mental state characterized by high concentration and focus on tasks that cause high pleasure and intrinsic motivation (Shernoff, Kratochwill, \& Stoiber, 2003). Studies on flow concluded that challenging

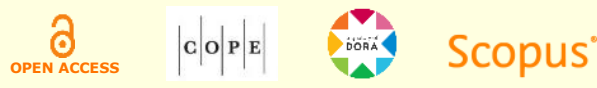


tasks lead to high concentration, absorption and immersion. Flow has been associated with learning, development of talent, academic performance and creative achievement, regardless of the task or job (Csikszentmihalyi, 1996; Csikszentmihalyi, Rathunde, \& Whalen, 1997). In their studies, Hamari and Koivisto (2014) and Procci, Singer, Levy and Bowers (2012) found that gamebased technologies promote and conjure up flow experiences capable of having a positive effect on the quality of learning and academic performance (Barzilai \& Blau, 2014; Brom et al., 2014; Chang, Wu, Weng, \& Sung, 2012; Hung, Sun, \& Yu, 2015; Sabourin \& Lester, 2014).

\section{Attitudes}

Attitudes remains one of the main interests of research in the social sciences, as it is widely accepted that attitudes are relevant for understanding and foreseeing social behavior (Ajzen, 2001). An attitude is a behavioral pattern that shows an individual's predisposition to adjust to designated social situations, a conditioned response to certain stimuli that lead to social experiences (LaPiere, 1934). Because it is a cross-cutting concept within the human and social sciences, it has been the subject of diversified and even competing approaches (Fredricks et al., 2004; Libbey, 2004; Poskitt \& Gibbs, 2010). In several studies, a behavioral component is usually mentioned (Beer, Clark, \& Jones, 2010; Fredricks et al., 2004), while, in others, students' attitudes towards education are discussed (Fredricks et al., 2004).

Attitudes shape one's behavior through a deliberate or spontaneous process; strong motivations can influence behaviors, attitudes, the subjective rules, and the perceived behavioral control (Albarracin \& Vargas, 2010; Banji \& Heiphetz, 2010). Regardless of the rules concerning public opinion on changing educational procedures, one cannot expect to find homogeneous attitudes among individuals, due to people having different personalities (Eaves \& Eysenck, 1974).

Attitudes towards education can be either positive or negative. The latter usually occurs when students are not involved in the teaching process of which they are part. This is usually an indicator of school dropout, because, when students are involved in school activities, they tend to persevere in fulfilling their goals, despite the challenges and obstacles they may face (Saeed \& Zyngier, 2012).

\section{Perceived learning}

As important agents of the teaching-learning process, instructors play an important role in their students' education, identity acquisition and development as members of a society and future professionals (Willemse, Lunenberg, \& Korthagen, 2005). Students' positive thinking about which of the methods used by instructors are the most experiential and interactive (Brown \& Lee, 1994; Frontczak, 1998; Mayer, 2003) is a precious indicator of a pedagogy of affection that helps students understand theoretical and practical knowledge they depend on to improve their learning (C. H. C. Hsu, 1999; Dunlosky, Rawson, Marsh, Nathan, \& Willingham, 2013; Rust, Price, \& O'Donovan, 2003; Tynjälä, 1999). The use of teaching methods that are aligned with the students' preferences and needs thus helps them develop more favorable attitudes to

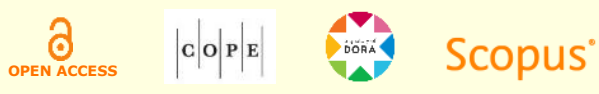


acquiring knowledge, feel more fulfilled, and reach higher levels of performance (Paswan \& Young, 2002; Sendaug \& Odabacsi, 2009; Young, Klemz, \& Murphy, 2003). This way, higher education institutions that possess a clear and innovating view of education and well-defined learning goals are better equipped to help their students become more productive and increase their interest, effectiveness and learning (Kolb \& Kolb, 2005; Pritchard, 2013; Silins \& Mulford, 2004; Young et al., 2003). That is why perceived learning analysis is so important, in so far as it has a positive impact on how students value what they are learning - although one can never be too careful when interpreting their opinions about the quality and usefulness of the teaching they have been offered (Frenzel, Pekrun, \& Goetz, 2007; Marks, 2000).

\section{Relationships among Constructs}

Of the 244 articles included in the current study, the ones entailing an empirical analysis were selected $(n=104)$ and results of empirical models were looked into in order to understand their relationship. The 104 empirical articles revealed statistically significant relationships among gamification's four main constructs. Some were obtained individually in one construct $(n=25)$, some in two constructs $(n=57)$, and some in three $(n=20)$ and in four $(n=2)$ constructs simultaneously (Table 1). The analysis showed the existence of cause-effect relationships among various constructs, most of which were statistically significant.

Table 1

Relationships among gamification's construct

\begin{tabular}{|c|c|c|c|c|}
\hline \multirow{2}{*}{ Authors } & \multicolumn{4}{|c|}{ Constructs } \\
\hline & MOT & FLO & ATT & PLE \\
\hline (Ding, Kim, \& Orey, 2017; Zamora \& Aranda, 2017) & $x$ & $\mathrm{x}$ & $x$ & $\mathrm{x}$ \\
\hline (Browne, Anand, \& Gosse, 2014) & $\mathrm{X}$ & $x$ & $\mathrm{X}$ & \\
\hline (Ahmed \& Sutton, 2017; Betts, Bal, \& Betts, 2013; Hamari et al., 2016) & $\mathrm{X}$ & $\mathrm{X}$ & & $\mathrm{X}$ \\
\hline $\begin{array}{l}\text { (Adukaite et al., 2017; Birch \& Woodruff, 2017; Borras-Gene, Martinez-Nunez, \& Fidalgo- } \\
\text { Blanco, 2016; de-Marcos, Garcia-Cabot, \& Garcia-Lopez, 2017; Domínguez et al., 2013; } \\
\text { Hakulinen, Auvinen, \& Korhonen, 2015; Hew, Huang, Chu, \& Chiu, 2016; Kirillov, Vinichenko, } \\
\text { Melnichuk, Melnichuk, \& Vinogradova, 2016; Landers \& Armstrong, 2017; Landers \& Landers, } \\
\text { 2014; Seixas, Gomes, \& de Melo Filho, 2016; Su \& Cheng, 2015) }\end{array}$ & $\mathrm{X}$ & & $x$ & $\mathrm{x}$ \\
\hline (Cózar-Gutiérrez \& Sáez-Lopéz, 2016) & $\mathrm{X}$ & $X$ & & \\
\hline (Armstrong \& Landers, 2017; Galbis-Córdova, Martí-Parreño, \& Currás-Pérez, 2017) & & & $\mathrm{X}$ & $x$ \\
\hline $\begin{array}{l}\text { (Codish \& Ravid, 2015; de-Marcos, Domínguez, Saenz-de-Navarrete, \& Pagés, 2014; Hanson- } \\
\text { Smith, 2016; Koivisto \& Hamari, 2014; Kuo \& Chuang, 2016; Mekler, Brithlmann, Tuch, \& Opwis, } \\
\text { 2017; Schoech et al., 2013) }\end{array}$ & $x$ & & $x$ & \\
\hline
\end{tabular}




\section{Table 1 (continued)}

\begin{tabular}{|c|c|c|c|c|}
\hline \multirow{2}{*}{ Authors } & \multicolumn{4}{|c|}{ Constructs } \\
\hline & MOT & FLO & ATT & PLE \\
\hline $\begin{array}{l}\text { (Alabbasi, 2017; Attali \& Arieli-Attali, 2015; Buckley \& Doyle, 2017; Bustillo, Rivera, Guzman, } \\
\text { \& Acosta, 2017; Cadavid \& Montoya Gómez, 2015; Cakiroglu, Basibuyuk, Guler, Atabay, \& } \\
\text { Memis, 2017; Carenys et al., 2017; C.-H. Chen, Liu, \& Hwang, 2016; Cheong, Filippou, \& } \\
\text { Cheong, 2014; Chubarkova, Sadchikov, Suslova, Tsaregorodtsev, \& Milova, 2016; Chun, } \\
\text { Youm, \& Oh, 2015; de-Marcos et al., 2016; Dias, 2017; Evans, 2016; Fernandez-Mesa, Olmos- } \\
\text { Penuela, \& Alegre, 2016; Garcia Gaitero, Costa Roman, \& Real Garcia, 2016; Geelan et al., } \\
\text { 2015; Gennari et al., 2017; González, Toledo, \& Muñoz, 2016; Hanus \& Fox, 2015; Hernando, } \\
\text { Arévalo, Mon, Batet, \& Catasús, 2015; H. Xu, Song, Yu, \& Tavares, 2017; Iwamoto, Hargis, } \\
\text { Taitano, \& Vuong, 2017; Kétyi, 2016; Khaleel, Ashaari, Wook, \& Ismail, 2016; Laskowski \& } \\
\text { Wojdyga, 2014; Leaning, 2015; L. Gonzalez, Gomez, \& Echeverri, 2017; Malas \& Hamtini, } \\
\text { 2016; Manrique-Losada, Gasca-Hurtado, \& Álvarez, 2015; Mladenovic, Krpan, \& Mladenovic, } \\
\text { 2016; Morillas Barrio, Munoz-Organero, \& Sanchez Soriano, 2016; Nebel, Beege, Schneider, } \\
\text { \& Rey, 2016; Pechenkina, Laurence, Oates, Eldridge, \& Hunter, 2017; Perryer, Celestine, } \\
\text { Scott-Ladd, \& Leighton, 2016; Sousa-Vieira, Lopez-Ardao, Fernandez-Veiga, Rodriguez- } \\
\text { Perez, \& Lopez-Garcia, 2015; Strmečki, Bernik, \& Radošević, 2015; Su \& Cheng, 2016; van } \\
\text { Rosmalen \& Westera, 2014) }\end{array}$ & $\mathrm{X}$ & & & $x$ \\
\hline $\begin{array}{l}\text { (Ašeriškis \& Damaševičius, 2017; Bartel \& Hagel, 2014; Buckley \& Doyle, 2016; Davis \& Singh, } \\
\text { 2015; de Freitas \& de Freitas, 2013; Gibson et al., 2015; Gopinath Bharathi, Singh, Tucker, \& } \\
\text { Nembhard, 2016; Hamzah, Ali, Saman, Yusoff, \& Yacob, 2015; Hasegawa, Koshino, \& Ban, } \\
\text { 2015; laremenko, 2017; Kopcha, Ding, Neumann, \& Choi, 2016; Müller, Reise, \& Seliger, } \\
\text { 2015; Osipov, Nikulchev, Volinsky, \& Prasikova, 2015; Pedersen et al., 2016; Pe-Than, Goh, } \\
\text { \& Lee, 2015; Sailer, Hense, Mayr, \& Mandl, 2017; Y. Chen, Burton, Mihaela, \& Whittinghill, } \\
\text { 2015) }\end{array}$ & $\mathrm{X}$ & & & \\
\hline (Hamari \& Koivisto, 2014) & & $\mathrm{X}$ & & \\
\hline (C.-L. Hsu, Chen, Yang, \& Lin, 2017) & & & $x$ & \\
\hline $\begin{array}{l}\text { (Brull, Finlayson, Kostelec, MacDonald, \& Krenzischeck, 2017; Christy \& Fox, 2014; de- } \\
\text { Marcos et al., 2016; Fan, Xiao, \& Su, 2015; Gudoniene, Bartkute, Rutkauskiene, \& } \\
\text { Blazauskas, 2016; Palomo-Duarte et al., 2016) }\end{array}$ & & & & $\mathrm{X}$ \\
\hline
\end{tabular}

The construct that stood out the most was motivation, tested in 94 of the 104 empirical articles, followed by perceived learning (76/104), attitudes (29/104) and, finally, flow (8/104). Motivation and perceived learning were more often flagged up (69/104), ahead of motivation with attitudes $(27 / 104)$ and motivation with flow (7/104). Only in two articles was a relationship tested (attitudes with perceived learning) without motivation having been analyzed. It follows, then, that motivation is gamification's main construct, and that perceived learning, attitudes and flow come next.

As per the relationships among three constructs, the most researched triad is motivation-attitudeslearning (16/104), followed by motivation-flow-attitudes (4/104) and motivation-flow-learning $(3 / 104)$. In only two articles, there is a relationship among the four constructs simultaneously.

Most of the relationships that were observed were statistically relevant, and most empirical articles show the following main relationships: motivation has a positive influence on perceived learning (Attali \& Arieli-Attali, 2015; Buckley \& Doyle, 2017; C.-H. Chen et al., 2016; de-Marcos et al., 2016; Filsecker \& Hickey, 2014; Gennari et al., 2017; Hanus \& Fox, 2015; Ibanez, Di-Serio, \& Delgado-Kloos, 2014; Simões et al., 2013), attitudes (Codish \& Ravid, 2015; Domínguez et al., 2014; Hanson-Smith, 2016; Koivisto \& Hamari, 2014; Kuo \& Chuang, 2016; Mekler et al., 2017; Schoech et al., 2013), and flow (Ahmed \& Sutton, 2017; Betts et al., 2013; Browne et al., 2014;

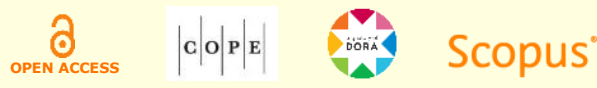


Cózar-Gutiérrez \& Sáez-López, 2016; Ding et al., 2017; Hamari et al., 2016). In turn, flow has a positive influence on perceived learning (Ahmed \& Sutton, 2017; Betts et al., 2013; Hamari et al., 2016), attitudes (Browne et al., 2014; Ding et al., 2017; Zamora \& Aranda, 2017), and motivation (Ahmed \& Sutton, 2017; Betts et al., 2013; Browne et al., 2014; Hamari et al., 2016). Finally, attitudes have a positive influence on perceived learning (Adukaite et al., 2017; Armstrong \& Landers, 2017; Birch \& Woodruff, 2017; Borras-Gene et al., 2016; Cózar-Gutiérrez \& Sáez-López, 2016; de-Marcos et al., 2017; Galbis-Córdova et al., 2017; Hew et al., 2016; Landers \& Armstrong, 2017).

\section{Conceptual Model}

We developed a conceptual model to ground future studies in the field (Figure 2).

The model shows the state of the art of gamification, its applicability, the main constructs, target audiences, and the type of organizations that use it. The main stakeholders using gamification in an educational context were identified, and the application of this tool to higher education was highlighted. Figure 2 presents the dimensions of education-applied gamification resulting from the literature review.

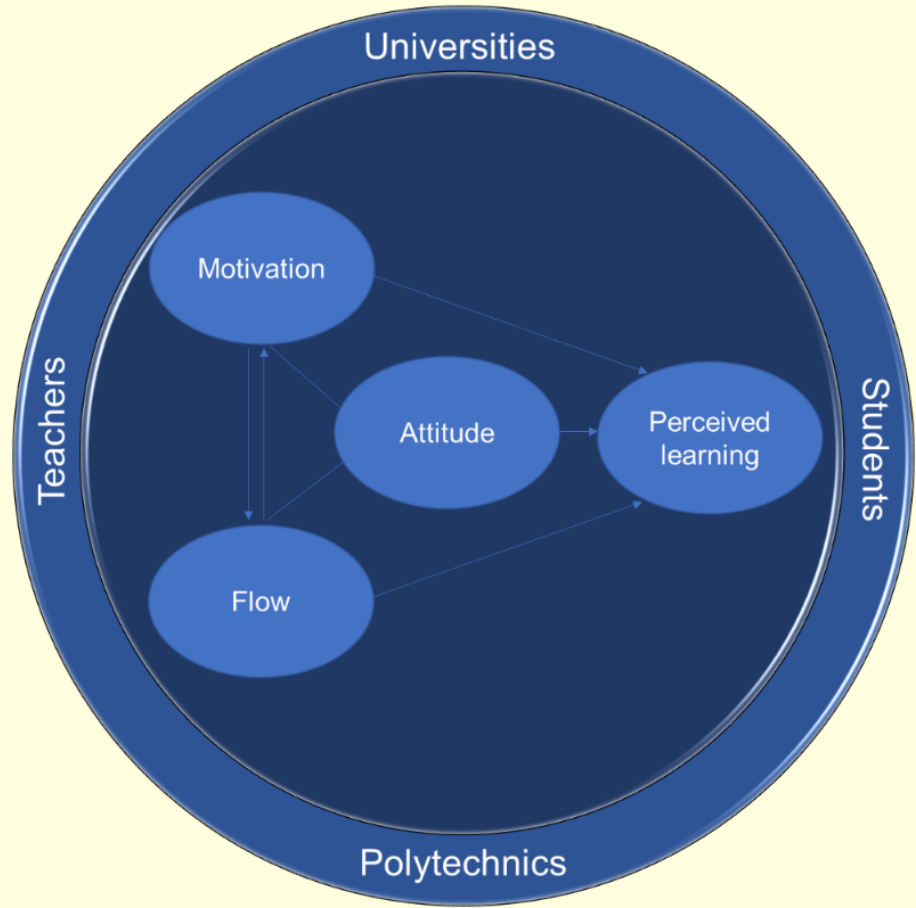

\section{Figure 2. Conceptual model}

From the systematic literature review, we verify that most relationships were statistically relevant, and most empirical studies show the following main relationships: motivation has a positive influence on perceived learning, on attitudes, and on flow. In turn, flow has a positive influence on perceived learning, on attitudes, and on motivation. Finally, attitudes have a positive influence 
on perceived learning. The proposal of this conceptual model will be important for researchers studying the effect of game-based resources on education in general and, in particular, on Management education, as this is an area where such teaching methodologies are clearly beneficial.

\section{Conclusions}

The main purpose of the present study was to develop a research conceptual model of Management-applied gamification through a systematic literature review. An overview of the most relevant literature on the subject led to the identification of the topics more frequently approached by the authors, namely: GBL supporting theories, gamification; serious games and Game-based Learning, gamification's main constructs, gamification applied to education, and gamification applied to management education.

The systematic literature review points to gamification having become more and more an object of scientific research, besides being a field with huge potential, but in need of expanding, since the available studies have their limitations and many of them are not robust enough nor do they have the capacity to extrapolate to the surrounding reality. The present research is a contribution to the advancement of scientific knowledge on the field that may help future research. Furthermore, it has led to a holistic systematizing of studies already conducted, identifying the most relevant authors who have approached the subject and continue to be a reference in the area. Although other analysis methods might have been used, resorting to various types of analysis has proven to be extremely useful in describing, systematizing and relating contents, given the diversity of the topics under study.

The present study's main contribution is to systematize the literature on game-based learning, filling in a gap as regards summarizing gamification's main basic theories and proposing a conceptual model that will enable further research, resulting from several studies on this field of knowledge.

The present article provides the reader with information on relevant publications included in the main scholarly databases, as well as on how they have contributed to this field of knowledge, the dimensions they have addressed, and the theories they draw on. The conceptual model that we propose allows future researchers to test empirical relationships besides suggesting others that may contribute to the advancement of literature

\section{Contributions}

Previous studies have stated that gamification in education can help promote learning in several areas, although its application in management has not been extensively addressed. The present study does a general review of the literature on game-based education in general, but looking especially into the case of Management as part of the administrative studies. In fact, this is the

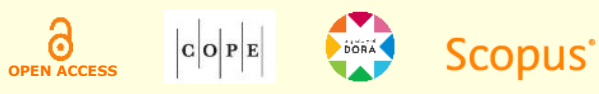


first study to extensively address this subject in a macro and micro dimension, contributing to advancing knowledge in this field and giving a detailed account of how the literature is organized.

The present systematic review provides an organized and structured starting point to the study of how the literature is sequenced, what has been done, what has been achieved, and the results and contributions of it for future research.

One of the major contributions is, no doubt, a systematic rigorous and complete review of the most relevant literature on gamification that made it possible to identify and look into how it has been generally applied, especially to education, its impact on learning, the type of teaching aids that have been used, how they have been used, and their contribution to the teaching-learning process in the various areas of management. In addition, the conceptual model that was created, stemming from the literature review, can help future researchers, providing them with a starting point that will lead the way of their research, by showing them which topics to approach and how to do it.

The extensive analysis of scientific articles also revealed the topics that still raise researchers' interest, namely those that can be controversial like the application of such theories as gamification, flow, self-determination, and planned behavior to show that gamification is not only a useful tool, but it can also actually help the learning process, regardless of the field in which it is applied.

Also important in this study is the way it refers to limitations that still persist when one tries to apply gamification to education. There is still much to do. Based on the present study, future research can expand in the study of applicability and effectiveness of game-based education, and, in particular, Management education. Finally, this has been a contribution to show gamification's increasingly important role in the evolution of education by way of the effect it has on students and instructors, distinguishing them in the traditional educational system.

\section{Limitations and future research}

This study has a limitation due to the fact that the systematic literature review is limited to ISI Web of Knowledge and Scopus databases, although these are also the two most well-recognized databases in scholarly fields. An additional limitation concerns the validation of findings, as it was limited do the authors' own analyses.

In terms of future research, we suggest that other empirical quantitative and qualitative studies be done on applying gamification to management education, as well as the impact of using gamebased resources on students' motivation, flow, attitudes and learning. Also, new games with different mechanics and principles as compared to those previously tested should be created and analyzed in terms of impacts. Another line of inquiry is to study more instructors and students in different contexts, as well as research methodologies that include control groups and gameadopting groups for comparison.

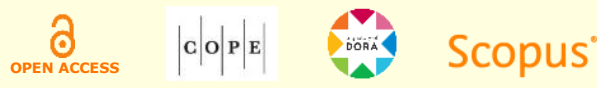


As regards to advancing theory, it is vital that the existing theories continue to be tested and, if possible, improved so that the true impact of gamification on education may be explained. Longitudinal studies are, thus, welcome to establish medium- and long-term impacts of gamification, allowing researchers to make more viable conclusions about the robustness of this type of studies, while developing the existing gamification theories and, eventually, creating new ones that will provide a more complete explanation of the phenomenon.

\section{References}

Abramovich, S., Schunn, C., \& Higashi, R. M. (2013). Are badges useful in education?: It depends upon the type of badge and expertise of learner. Educational Technology Research and Development, 61(2), 217-232. https://doi.org/10.1007/s11423-013-9289-2

Adukaite, A., Zyl, I. van, Er, S., \& Cantoni, L. (2017). Teacher perceptions on the use of digital gamified learning in tourism education: The case of South African secondary schools. Computers $\mathcal{E}$ Education, 111, 172-190. https://doi.org/10.1016/j.compedu.2017.04.008

Ahmed, A., \& Sutton, M. J. D. (2017). Gamification, serious games, simulations, and immersive learning environments in knowledge management initiatives. World Journal of Science Technology and Sustainable Development, 14(2-3), 78-83. https://doi.org/10.1108/wjstsd-02-2017-0005

Ajzen, I. (1991). The theory of planned behavior. Organizational Behavior and Human Decision Processes, 50(2), 179211. https://doi.org/10.1016/0749-5978(91)90020-T

Ajzen, I. (2001). Nature and operation of attitudes. Annual Review of Psychology, 52(1), 27-58. https://doi.org/10.1146/annurev.psych.52.1.27

Alabbasi, D. (2017). Exploring graduate students' perspectives towards using gamification techniques in online learning. Turkish Online Journal of Distance Education, 18(3), 180-196. https://doi.org/10.17718/tojde.328951

Albarracin, D., \& Vargas, P. (2010). Attitudes and persuasion: From biology to social responses to persuasive intent. Handbook of Social Psychology, 57, 394-427. https://doi.org/10.1002/9780470561119.socpsy001011

Albrecht, W. D. (1995). A financial accounting and investment simulation game. Issues in Accounting Education, 10(1), 127-142.

Antonaci, A., Dagnino, F. M., Ott, M., Bellotti, F., Berta, R., De Gloria, A., Lavagnino, E., Romero, M., Usart, M., \& Mayer, I. (2015). A gamified collaborative course in entrepreneurship: Focus on objectives and tools. Computers in Human Behavior, 51(B), 1276-1283. https://doi.org/10.1016/j.chb.2014.11.082

Appleton, J. J., Christenson, S. L., \& Furlong, M. J. (2008). Student engagement with school: Critical conceptual and methodological issues of the construct. Psychology in the Schools, 45(5), 369-386. https://doi.org/10.1002/pits.20303

Arias Aranda, D., Bustinza Sanchez, O. F., \& Djundubaev, R. (2016). Effects of gamified business simulations on entrepreneurial attitude at high school level. Revista de Educacion, (371), 133-156. https://doi.org/10.4438/1988592X-RE-2015-371-311

Armitage, H. M., Webb, A., \& Glynn, J. (2016). The use of management accounting techniques by small and medium-sized enterprises: A field study of Canadian and Australian practice. Accounting Perspectives, 15(1), 31-69. https://doi.org/10.1111/1911-3838.12089

Armstrong, M. B., \& Landers, R. N. (2017). An evaluation of gamified training: using narrative to improve reactions and learning. Simulation and Gaming, 48(4), 513-538. Retrieved from https://www.scopus.com/inward/record.uri?eid=2-s2.0-

85026851586\& doi $=10.1177 \% 2 F 1046878117703749 \&$ partnerID=40\& md5=6b8b4c8a268d7b98c8f74caf4611 c0ed

Ašeriškis, D., \& Damaševičius, R. (2017). Computational evaluation of effects of motivation reinforcement on player retention. Journal of Universal Computer Science, 23(5), 432-453. http://dx.doi.org/10.3217/jucs-023-05-0432

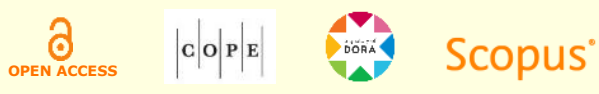


Attali, Y., \& Arieli-Attali, M. (2015). Gamification in assessment: Do points affect test performance? Computers $\mathcal{E}$ Education, 83, 57-63. https://doi.org/10.1016/j.compedu.2014.12.012

Avramenko, A. (2012). Enhancing students' employability through business simulation. Education+ Training, 54(5), 355-367. https://doi.org/10.1108/00400911211244669

Bagley, K. S. (2012). Conceptual mile markers to improve time-to-value for exploratory search sessions (Doctoral dissertation). University of Massachusetts Lowell, Lowell, MA, USA.

Banji, M. R., \& Heiphetz, L. (2010). Handbook of social psychology. In S. T. Fiske, D. T. Gilbert, \& G. Lindzey (Eds.), Handbook of social psychology (pp. 353-393). Hoboken, NJ: John Wiley \& Sons.

Banks, J. A. (2008). Diversity, group identity, and citizenship education in a global age. Educational Researcher, 37(3), 129-139. https://doi.org/10.3102/0013189x08317501

Bartel, A., \& Hagel, G. (2014). Engaging students with a mobile game-based learning system in university education. International Journal of Interactive Mobile Technologies, 8(4), 56-60. https://doi.org/10.3991/ijim.v8i4.3991

Barzilai, S., \& Blau, I. (2014). Scaffolding game-based learning: Impact on learning achievements, perceived learning, and game experiences. Computers $\mathcal{E}$ Education, 70, 65-79. https://doi.org/10.1016/j.compedu.2013.08.003

Beelmann, A. (2006). Review of systematic reviews in the social sciences. A practical guide. European Psychologist, 11(3), 244-245. http://dx.doi.org/10.1027/1016-9040.11.3.244

Beer, C., Clark, K., \& Jones, D. (2010, December). Indicators of engagement. Proceedings of Ascilite 2010 Conference, Sydney, Australia, 27.

Bee, S., \& Hayes, D. C. (2011). Using the jeopardy game to enhance student understanding of accounting information systems (AIS) exam material. Review of Business Information Systems (RBIS), 9(1), 69-78. https://doi.org/10.19030/rbis.v9i1.4471

Bellotti, F., Berta, R., De Gloria, A., Lavagnino, E., Antonaci, A., Dagnino, F. M., \& Ott, M. (2013, July). A gamified short course for promoting entrepreneurship among ICT engineering students. 2013 IEEE International Conference on Advanced Learning Technologies, Beijing, China, 13. https://doi.org/10.1109/ICALT.2013.14

Betts, B. W., Bal, J., \& Betts, A. W. (2013). Gamification as a tool for increasing the depth of student understanding using a collaborative e-learning environment. International Journal of Continuing Engineering Education and Life-Long Learning, 23(3-4), 213-228. https://doi.org/10.1504/ijceell.2013.055405

Biggs, J. (1999). What the student does: Teaching for enhanced learning. Higher Education Research Eु Development, 18(1), 57-75. https://doi.org/10.1080/0729436990180105

Birch, H. J. S., \& Woodruff, E. (2017). Technical exercise practice: Can piano students be motivated through gamification? Journal of Music, Technology and Education, 10(1), 31-50. https://doi.org/10.1386/jmte.10.1.31_1

Borras-Gene, O., Martinez-Nunez, M., \& Fidalgo-Blanco, A. (2016). New challenges for the motivation and learning in engineering education using gamification in MOOC. IIternational Journal of Engineering Education, 32(1, B), 501-512.

Brom, C., Buchtová, M., Šisler, V., Děchtěrenko, F., Palme, R., \& Glenk, L. M. (2014). Flow, social interaction anxiety and salivary cortisol responses in serious games: A quasi-experimental study. Computers $\mathcal{E}$ Education, 79, 69-100. https://doi.org/10.1016/j.compedu.2014.07.001

Brophy, J. E. (2013). Motivating students to learn. New York, NY: Routledge.

Browne, K., Anand, C., \& Gosse, E. (2014). Gamification and serious game approaches for adult literacy tablet software. Entertainment Computing, 5(3), 135-146. https://doi.org/10.1016/j.entcom.2014.04.003

Brown, H. D., \& Lee, H. (1994). Teaching by principles: An interactive approach to language pedagogy (Vol. 1). Englewood Cliffs, NJ: Prentice Hall Regents.

Brull, S., Finlayson, S., Kostelec, T., MacDonald, R., \& Krenzischeck, D. (2017). Using gamification to improve productivity and increase knowledge retention during orientation. Journal of Nursing Administration, 47(9), 448453. https://doi.org/10.1097/NNA.0000000000000512

Brunsell, E., \& Horejsi, M. (2011). "Flipping" your classroom. The Science Teacher, 78(2), 10. Retrieved from http://www.jstor.org/stable/24148320

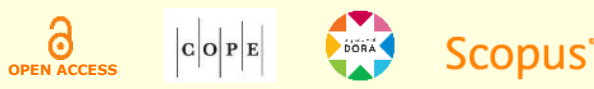


Buckley, P., \& Doyle, E. (2016). Gamification and student motivation. Interactive Learning Environments, 24(6), 1162 1175. https://doi.org/10.1080/10494820.2014.964263

Buckley, P., \& Doyle, E. (2017). Individualising gamification: An investigation of the impact of learning styles and personality traits on the efficacy of gamification using a prediction market. Computers and Education, 106, 43-55 https://doi.org/10.1016/j.compedu.2016.11.009

Bustillo, J., Rivera, C., Guzman, J. G., \& Acosta, L. R. (2017). Benefits of using a mobile application in learning a foreign language. Sistemas $\mathcal{E}$ Telematica, 15(40), 55-68. https://doi.org/10.18046/syt.v15i40.2391

Cadavid, J. M., \& Montoya Gómez, L. F. (2015). Use of a gamified virtual learning environment as didactic strategy in a pre-calculus course: Case study in the National University of Colombia. Revista Iberica de Sistemas e Tecnologias de Informação, 2015(16), 1-16. https://doi.org/10.17013/risti.16.1-16

Cakiroglu, U., Basibuyuk, B., Guler, M., Atabay, M., \& Memis, B. Y. (2017). Gamifying an ICT course: Influences on engagement and academic performance. Computers in Human Behavior, 69, 98-107. https://doi.org/10.1016/j.chb.2016.12.018

Camilleri, V., Busuttil, L., \& Montebello, M. (2011). Social interactive learning in multiplayer games. In M. Ma, A. Oikonomou, \& L. C. Jain (Eds.), Serious games and edutainment applications (pp. 481-501). London, UK: SpringerVerlag London.

Carenys, J., Moya, S., \& Perramon, J. (2017). Is it worth it to consider videogames in accounting education? A comparison of a simulation and a videogame in attributes, motivation and learning outcomes. Revista de Contabilidad, 20(2), 118-130. https://doi.org/10.1016/j.rcsar.2016.07.003

Ceschi, A., Dorofeeva, K., \& Sartori, R. (2014). Studying teamwork and team climate by using a business simulation: How communication and innovation can improve group learning and decision-making performance. European Journal of Training and Development, 38(3), 211-230. https://doi.org/10.1108/ejtd-01-2013-0004

Chang, K.-E., Wu, L.-J., Weng, S.-E., \& Sung, Y.-T. (2012). Embedding game-based problem-solving phase into problem-posing system for mathematics learning. Computers $\mathscr{E}$ Education, 58(2), 775-786. https://doi.org/10.1016/j.compedu.2011.10.002

Charles, D., Charles, T., McNeill, M., Bustard, D., \& Black, M. (2011). Game-based feedback for educational multiuser virtual environments. British Journal of Educational Technology, 42(4), 638-654. https://doi.org/10.1111/j.1467-8535.2010.01068.x

Chen, C.-H., Liu, G.-Z., \& Hwang, G.-J. (2016). Interaction between gaming and multistage guiding strategies on students' field trip mobile learning performance and motivation. British Journal of Educational Technology, 47(6), 1032-1050. https://doi.org/10.1111/bjet.12270

Chen, C.-Y., Chen, P.-C., \& Chen, P.-Y. (2014). Total quality management \& business excellence teaching quality in higher education: An introductory review on a process- oriented teaching-quality model. Total Quality Management $\mathcal{E}$ Business Excellence, 25(1-2), 36-56. https://doi.org/10.1080/14783363.2011.637789

Chen, Y., Burton, T., Mihaela, V., \& Whittinghill, D. M. (2015). Cogent: A case study of meaningful gamification in education with virtual currency. International Journal of Emerging Technologies in Learning, 10(1), 39-45. https://doi.org/10.3991/ijet.v10i1.4247

Cheong, C., Filippou, J., \& Cheong, F. (2014). Towards the gamification of learning: Investigating student perceptions of game elements. Journal of Information Systems Education, 25(3), 233-244

Christy, K. R., \& Fox, J. (2014). Leaderboards in a virtual classroom: A test of stereotype threat and social comparison explanations for women's math performance. Computers $\mathcal{E}$ Education, $78, \quad 66-77$. https://doi.org/10.1016/j.compedu.2014.05.005

Chubarkova, E. V, Sadchikov, I. A., Suslova, I. A., Tsaregorodtsev, A. A., \& Milova, L. N. (2016). Educational game systems in artificial intelligence course. International Journal of Environmental and Science Education, 11(16), 92559265. Retrieved from http://www.ijese.net/makale/1162

Chun, Y., Youm, K., \& Oh, K. (2015). Difficulty balancing and review management system for smart mobile learning. Intermational Journal of Multimedia and Ubiquitous Engineering, 10(1), 219-226. https://doi.org/10.14257/ijmue.2015.10.1.21

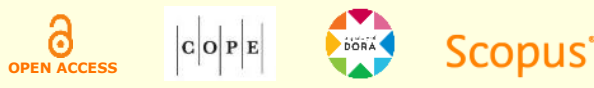


Clark, M. C., \& Rossiter, M. (2008). Narrative learning in adulthood. New Directions for Adult and Continuing Education, 2008(119), 61-70. https://doi.org/10.1002/ace.306

Codish, D., \& Ravid, G. (2015). Detecting playfulness in educational gamification through behavior patterns. IBM Journal of Research and Development, 59(6), 1-14. https://doi.org/10.1147/JRD.2015.2459651

Cohen, K. J., \& Rhenman, E. (1961). The role of management games in education and research. Management Science, 7(2), 131-166. https://doi.org/10.1287/mnsc.7.2.131

Connolly, T. M., Boyle, E. A., MacArthur, E., Hainey, T., \& Boyle, J. M. (2012). A systematic literature review of empirical evidence on computer games and serious games. Computers Ë Education, 59(2), 661-686. https://doi.org/10.1016/j.compedu.2012.03.004

Conway, S. (2014). Zombification?: Gamification, motivation, and the user. Journal of Gaming and Virtual Worlds, 6(2), 129-141. https://doi.org/10.1386/jgvw.6.2.129_1

Cook, E. D. (1997). An innovative method of classroom presentation: What is "Jeopardy?" Journal of Accounting Education, 15(1), 123-131. https://doi.org/10.1016/s0748-5751(96)00045-0

Cózar-Gutiérrez, R., \& Sáez-López, J. M. (2016). Game-based learning and gamification in initial teacher training in the social sciences: An experiment with MinecraftEdu. International Journal of Educational Technology in Higher Education, 13(1), 1-11. https://doi.org/10.1186/s41239-016-0003-4

Csikszentmihalyi, M. (1990). The domain of creativity. In M. A. Runco, \& R.S. Albert (Eds.), Theories of creativity (pp. 190-212). Newbury Park, CA: Sage.

Csikszentmihalyi, M. (1996). Flow and the psychology of discovery and invention. New York, NY: Harper Collins.

Csikszentmihalyi, M., Rathunde, K., \& Whalen, S. (1997). Talented teenagers: The roots of success and failure. Cambridge, UK: Cambridge University Press.

Dale, S. (2014). Gamification: Making work fun, or making fun of work? Business Information Review, 31(2), 82-90. https://doi.org/10.1177/0266382114538350

Darejeh, A., \& Salim, S. S. (2016). Gamification solutions to enhance software user engagement: A systematic review. International Journal of Human-Computer Interaction, 32(8), 613-642. https://doi.org/10.1080/10447318.2016.1183330

Davis, K., \& Singh, S. (2015). Digital badges in afterschool learning: Documenting the perspectives and experiences of students and educators. Computers $\mathcal{E}$ Education, 88, 72-83. https://doi.org/10.1016/j.compedu.2015.04.011

Deci, E. L., Koestner, R., \& Ryan, R. M. (2001). Extrinsic rewards and intrinsic motivation in education: Reconsidered once again. Review of Educational Research, 71(1), 1-27. https://doi.org/10.3102/00346543071001001

Deci, E. L., \& Ryan, R. M. (1985). The general causality orientations scale: Self-determination in personality. Journal of Research in Personality, 19(2), 109-134. https://doi.org/10.1016/0092-6566(85)90023-6

de Freitas, A. A., \& de Freitas, M. M. (2013). Classroom live: A software-assisted gamification tool. Computer Science Education, 23(2), 186-206. https://doi.org/10.1080/08993408.2013.780449

de-Marcos, L., Dominguez, A., Saenz-de-Navarrete, J., \& Pagés, C. (2014). An empirical study comparing gamification and social networking on e-learning. Computers \&ु Education, 75, 82-91. https://doi.org/10.1016/j.compedu.2014.01.012

de-Marcos, L., Garcia-Cabot, A., \& Garcia-Lopez, E. (2017). Towards the social gamification of e-learning: A practical experiment. International Journal of Engineering Education, 33(1), 66-73. Retrieved from https://www.scopus.com/inward/record.uri?eid=2-s2.0$85015255902 \&$ partnerID $=40 \&$ md5=e6b77324147eb9671a49e0807ca05f21

de-Marcos, L., Garcia-Lopez, E., Garcia-Cabot, A., Medina-Merodio, J.-A., Dominguez, A., Javier Martinez-Herraiz, J., \& Diez-Folledo, T. (2016). Social network analysis of a gamified e-learning course: Small-world phenomenon and network metrics as predictors of academic performance. Computers in Human Behavior, 60, $312-321$. https://doi.org/10.1016/j.chb.2016.02.052

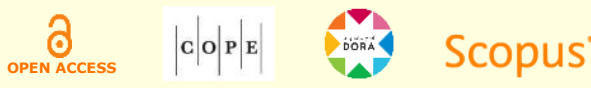


Denny, P. (2013, April-May). The effect of virtual achievements on student engagement. Proceedings of the SIGCHI Conference on Human Factors in Computing Systems, Paris, France, 13.

Deterding, S. (2012). Gamification: Designing for motivation. Interactions, 19(4), 14-17. https://doi.org/10.1145/2212877.2212883

Deterding, S., Dixon, D., Khaled, R., \& Nacke, L. (2011, September). From game design elements to gamefulness: Defining gamification. Proceedings of the International Academic MindTrek Conference: Envisioning Future Media Environments, Tampere, Finland, 15.

Deterding, S., Sicart, M., Nacke, L., O’Hara, K., \& Dixon, D. (2011, May). Gamification. using game-design elements in non-gaming contexts. CHI'11 Extended Abstracts on Human Factors in Computing Systems, Vancouver, BC, Canada.

Dias, J. (2017). Teaching operations research to undergraduate management students: The role of gamification. International Journal of Management Education, 15(1), 98-111. https://doi.org/10.1016/j.ijme.2017.01.002

Dichev, C., \& Dicheva, D. (2017). Gamifying education: What is known, what is believed and what remains uncertain: A critical review. International Journal of Educational Technology in Higher Education, 14(9), 1-36. https://doi.org/10.1186/s41239-017-0042-5

Dicheva, D., Dichev, C., Agre, G., \& Angelova, G. (2015). Gamification in education: A systematic mapping study. Educational Technology $\mathcal{E}$ Society, 18(3), 75-88. Retrieved from https://www.j-ets.net/ETS/journals/18_3/6.pdf

Ding, L., Kim, C., \& Orey, M. (2017). Studies of student engagement in gamified online discussions. Computers and Education, 115, 126-142. https://doi.org/10.1016/j.compedu.2017.06.016

Domínguez, A., Saenz-de-Navarrete, J., de-Marcos, L., Fernández-Sanz, L., Pagés, C., \& Martínez-Herráiz, J.-J. (2013). Gamifying learning experiences: Practical implications and outcomes. Computers EF Education, 63, $380-392$. https://doi.org/10.1016/j.compedu.2012.12.020

Domínguez, A., Saenz-de-navarrete, J., \& Pagés, C. (2014). An empirical study comparing gamification and social networking on e-learning. Computers $\mathscr{E}$ Education, 75, 82-91. https://doi.org/10.1016/j.compedu.2014.01.012

Downes-Le Guin, T., Baker, R., Mechling, J., \& Ruyle, E. (2012). Myths and realities of respondent engagement in online surveys. International Journal of Market Research, 54(5), 1-21. https://doi.org/10.2501/ijmr-54-5-613-633

Dunlosky, J., Rawson, K. A., Marsh, E. J., Nathan, M. J., \& Willingham, D. T. (2013). Improving students' learning with effective learning techniques: Promising directions from cognitive and educational psychology. Psychological Science in the Public Interest, 14(1), 4-58. https://doi.org/10.1177/1529100612453266

Eaves, L. J., \& Eysenck, H. (1974). Genetics and the development of social attitudes. Nature, 249, 288-289. https://doi.org/10.1038/249288a0

Evans, E. (2016). Gamification in a year 10 latin classroom: Ineffective 'edutainment' or a valid pedagogical tool? Journal of Classics Teaching, 17(34), 1-13. https://doi.org/10.1017/S2058631016000192

Fan, K.-K., Xiao, P., \& Su, C.-H. (2015). The effects of learning styles and meaningful learning on the learning achievement of gamification health education curriculum. Eurasia Journal of Mathematics Science and Technology Education, 11(5), 1211-1229. https://doi.org/10.12973/eurasia.2015.1413a

Fernandez-Mesa, A., Olmos-Penuela, J., \& Alegre, J. (2016). Pedagogical value of a common knowledge repository for Business Management courses. @tic revista d'educació educativa, (16), 39-47. https://doi.org/10.7203/attic.16.8044

Filsecker, M., \& Hickey, D. T. (2014). A multilevel analysis of the effects of external rewards on elementary students' motivation, engagement and learning in an educational game. Computers $\mathcal{E}$ Education, 75, 136-148. https://doi.org/10.1016/j.compedu.2014.02.008

Finn, J. D., Pannozzo, G. M., \& Voelkl, K. E. (1995). Disruptive and inattentive-withdrawn behavior and achievement among fourth graders. The Elementary School Journal, 95(5), 421-434. https://doi.org/10.1086/461853

Fitó-Bertran, A., Hernández-Lara, A. B., \& Serradell-López, E. (2014). Comparing student competences in a face-toface and online business game. Computers in Human Behavior, 30, $452-459$. https://doi.org/10.1016/j.chb.2013.06.023

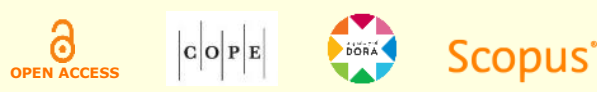


Foster, J. A., Sheridan, P. K., Irish, R., \& Frost, G. S. (2012, June). Gamification as a strategy for promoting deeper investigation in a reverse engineering activity. Paper presented at 2012 ASEE Annual Conference \& Exposition, San Antonio, Texas. Retrieved from https://peer.asee.org/21419

Fratto, V. A. (2012). Enhance student learning with powerpoint games: Using twenty questions to promote active. In L. A. Tomei (Ed.), Learning tools and teaching approaches through ICT advancements (pp. 23-30). Hershey, PA: IGI Global.

Fredricks, J. A., Blumenfeld, P. C., \& Paris, A. H. (2004). School engagement: Potential of the concept, state of the evidence. Review of Educational Research, 74(1), 59-109. https://doi.org/10.3102/00346543074001059

Frenzel, A. C., Pekrun, R., \& Goetz, T. (2007). Perceived learning environment and students' emotional experiences: A multilevel analysis of mathematics classrooms. Learning and Instruction, 17(5), 478-493. https://doi.org/10.1016/j.learninstruc.2007.09.001

Frontczak, N. T. (1998). A paradigm for the selection, use and development of experiential learning activities in marketing education. Marketing Education Review, 8(3), 25-33. https://doi.org/10.1080/10528008.1998.11488641

Galbis-Córdova, A., Martí-Parreño, J., \& Currás-Pérez, R. (2017). Higher education students' attitude towards the use of gamification for competencies development. Journal of E-Learning and Knowledge Society, 13(1), 129-146. Retrieved from http://www.je-lks.org/ojs/index.php/Je-LKS_EN/article/view/1279/1058

Garcia Gaitero, O., Costa Roman, O., \& Real Garcia, J. J. (2016). Triangulation of successful sources in teaching: learning styles, gamification and self-regulated learning. Joumal of Leaming Styles, 9(18), 117-134. Retrieved from http://learningstyles.uvu.edu/index.php/jls/article/view/291/219

Gåsland, M. M. (2011). Game mechanic based e-learning: A case study (Master thesis). Institutt for datateknikk og informasjonsvitenskap, Gjøvik, Norway .

Geelan, B., de Salas, K., Lewis, I., King, C., Edwards, D., \& O’Mara, A. (2015). Improving learning experiences through gamification: A case study. Australian Educational Computing, 30(1), 1-21. Retrieved from http://journal.acce.edu.au/index.php/AEC/article/view/57

Gennari, R., Melonio, A., Raccanello, D., Brondino, M., Dodero, G., Pasini, M., \& Torello, S. (2017). Children’s emotions and quality of products in participatory game design. International Journal of Human-Computer Studies, 101, 45-61. https://doi.org/10.1016/j.ijhcs.2017.01.006

Gibson, D., Ostashewski, N., Flintoff, K., Grant, S., \& Knight, E. (2015). Digital badges in education. Education and Information Technologies, 20(2), 403-410. https://doi.org/10.1007/s10639-013-9291-7

Glover, I. (2013). Play as you learn: Gamification as a technique for motivating learners. Proceedings of World Conference on Educational Multimedia, Hypermedia and Telecommunications, Chesapeake, VA.

Goehle, G. (2013). Gamification and web-based homework. Primus, 23(3), 234-246. https://doi.org/10.1080/10511970.2012.736451

González, C., \& Area, M. (2013). Breaking the rules: Gamification of learning and educational materials. Proceedings of the International Workshop on Interaction Design in Educational Environments, Portugal, 2. https://doi.org/0.5220/0004600900470053

González, C. S., Toledo, P., \& Muñoz, V. (2016). Enhancing the engagement of intelligent tutorial systems through personalization of gamification. International Journal of Engineering Education, 32(1, B, SI), $532-541$.

Gonzalez, L., Gomez, M. C., \& Echeverri, J. A. (2017). Motivation and virtual education in computer science: Case Universidad de Medellin-Colombia. IEEE Latin America Transactions, 15(6), 1176-1181. https://doi.org/10.1109/tla.2017.7932706

Gopinath Bharathi, A. K. B., Singh, A., Tucker, C. S., \& Nembhard, H. B. (2016). Knowledge discovery of game design features by mining user-generated feedback. Computers in Human Behavior, 60, 361-371. https://doi.org/10.1016/j.chb.2016.02.076

Greenberg, B. S., Sherry, J., Lachlan, K., Lucas, K., \& Holmstrom, A. (2010). Orientations to video games among gender and age groups. Simulation $\mathcal{E}$ Gaming, 41(2), 238-259. https://doi.org/10.1177/1046878108319930

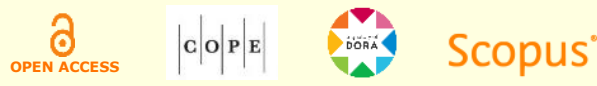


Griffiths, M. D., Davies, M. N. O., \& Chappell, D. (2003). Breaking the stereotype: The case of online gaming. CyberPsychology E Behavior, 6(1), 81-91. https://doi.org/10.1089/109493103321167992

Gudoniene, D., Bartkute, R., Rutkauskiene, D., \& Blazauskas, T. (2016). Technological aspects of the gamification model for e-learning participant's engagement. Baltic Journal of Modern Computing, 4(4), 1008-1015. https://doi.org/10.22364/bjmc.2016.4.4.25

Hakulinen, L., Auvinen, T., \& Korhonen, A. (2015). The effect of achievement badges on students' behavior: An empirical study in a university-level computer science course. International Journal of Emerging Technologies in Learning, 10(1), 18-29. https://doi.org/10.3991/ijet.v10i1.4221

Hamari, J. (2013). Transforming homo economicus into homo ludens: A field experiment on gamification in a utilitarian peer-to-peer trading service. Electronic Commerce Research and Applications, 12(4), 236-245. https://doi.org/10.1016/j.elerap.2013.01.004

Hamari, J., \& Koivisto, J. (2014). Measuring flow in gamification: Dispositional flow scale-2. Computers in Human Behavior, 40, 133-143. https://doi.org/10.1016/j.chb.2014.07.048

Hamari, J., \& Koivisto, J. (2015). Why do people use gamification services? International Joumal of Information Management, 35(4), 419-431. https://doi.org/10.1016/j.ijinfomgt.2015.04.006

Hamari, J., Koivisto, J., \& Sarsa, H. (2014, January). Does gamification work?-a literature review of empirical studies on gamification. Hawaii International Conference On, Waikoloa, HI, USA, 47. https://doi.org/10.1109/hicss.2014.377

Hamari, J., Shernoff, D. J., Rowe, E., Coller, B., Asbell-Clarke, J., \& Edwards, T. (2016). Challenging games help students learn: An empirical study on engagement, flow and immersion in game-based learning. Computers in Human Behavior, 54, 170-179. https://doi.org/10.1016/j.chb.2015.07.045

Hamzah, W. M. A. F. W., Ali, N. H., Saman, M. Y. M., Yusoff, M. H., \& Yacob, A. (2015). Influence of gamification on students' motivation in using E-learning applications based on the motivational design model. International Journal of Emerging Technologies in Learning, 10(2), 30-34. https://doi.org/10.3991/ijet.v10i1.4355

Hanson-Smith, E. (2016). Games, gaming, and gamification: Some aspects of motivation. Tesol Journal, 7(1), 227 232. https://doi.org/10.1002/tesj.233

Hanus, M. D., \& Fox, J. (2015). Assessing the effects of gamification in the classroom: A longitudinal study on intrinsic motivation, social comparison, satisfaction, effort, and academic performance. Computers and Education, 80, 152-161. https://doi.org/10.1016/j.compedu.2014.08.019

Harlen, W., \& Crick, R. D. (2003). Testing and motivation for learning. Assessment in Education: Principles, Policy $\mathcal{E}$ Practice, 10(2), 169-207. https://doi.org/10.1080/0969594032000121270

Hasegawa, T., Koshino, M., \& Ban, H. (2015). An English vocabulary learning support system for the learner's sustainable motivation. SpringerPlus, 4(1), 1-9. https://doi.org/10.1186/s40064-015-0792-2

Hattie, J., \& Timperley, H. (2007). The power of feedback. Review of Educational Research, 77(1), 81-112. https://doi.org/10.3102/003465430298487

Hellwege, B., \& Robertson, C. (2012, October). Entertain, engage, educate. Proceedings of Australian Computers in Education Conference, Perth, Australia.

Hernando, M. M., Arévalo, C. G., Mon, C. Z., Batet, L. A., \& Catasús, M. G. (2015). Play the game: Gamification and healthy habits in physical education [Play the game: Ludificació i hàbits saludables en l'educació física]. Apunts Educacion Fisica y Deportes, (119), 71-79. https://doi.org/10.5672/apunts.2014-0983.es.(2015/1).119.04

Hew, K. F., Huang, B., Chu, K. W. S., \& Chiu, D. K. W. (2016). Engaging Asian students through game mechanics: Findings from two experiment studies. Computers $\mathcal{E}$ Education, 92-93, 221-236. https://doi.org/10.1016/j.compedu.2015.10.010

Hickey, D. T., \& Rehak, A. (2013). Wikifolios and participatory assessment for engagement, understanding, and achievement in online courses. Journal of Educational Multimedia and Hypermedia, 22(4), 407-441.

Hill, F. M. (1995). Managing service quality in higher education: The role of the student as primary consumer. Quality Assurance in Education, 3(3), 10-21. https://doi.org/10.1108/09684889510093497

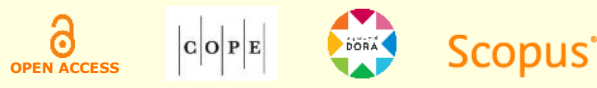


Hsu, C. H. C. (1999). Learning styles of hospitality students: Nature or nurture? International Journal of Hospitality Management, 18(1), 17-30. https://doi.org/10.1016/s0278-4319(98)00045-0

Hsu, C.-L., Chen, Y.-C., Yang, T.-N., \& Lin, W.-K. (2017). Do website features matter in an online gamification context? Focusing on the mediating roles of user experience and attitude. Telematics and Informatics, 34(4), 196205. https://doi.org/10.1016/j.tele.2017.01.009

Huang, W. H.-Y., \& Soman, D. (2013, December 10). Gamification of education. Research Report Series: Behavioural Economics in Action, Rotman School of Management, University of Toronto, Toronto, CAN. Retrieved from http://www.rotman.utoronto.ca/-/media/files/programs-and-areas/behaviouraleconomics/guidegamificationeducationdec2013.pdf

Hung, C.-Y., Sun, J. C.-Y., \& Yu, P.-T. (2015). The benefits of a challenge: student motivation and flow experience in tablet-PC-game-based learning. Interactive Learning Environments, 23(2), $172-190$. https://doi.org/10.1080/10494820.2014.997248

Huotari, K., \& Hamari, J. (2012, October). Defining gamification - A service marketing perspective. Proceeding of the International Academic MindTrek Conference on - MindTrek '12, Tampere, Finland, 12. https://doi.org/10.1145/2393132.2393137

Huotari, K., \& Hamari, J. (2017). A definition for gamification: Anchoring gamification in the service marketing literature. Electronic Markets, 27(1), 21-31. https://doi.org/10.1007/s12525-015-0212-z

Iaremenko, N. V. (2017). Enhancing English language learners' motivation through online games. Information Technologies and Learning Tools, 59(3), 126-133. https://doi.org/10.33407/itlt.v59i3.1606

Ibanez, M.-B., Di-Serio, A., \& Delgado-Kloos, C. (2014). Gamification for engaging computer science students in learning activities: A case study. IEEE Transactions on Learning Technologies, 7(3), 291-301. https://doi.org/10.1109/TLT.2014.2329293

Iwamoto, D. H., Hargis, J., Taitano, E. J., \& Vuong, K. (2017). Analyzing the efficacy of the testing effect using KahootTM on student performance. Turkish Online Journal of Distance Education, 18(2), 80-93. https://doi.org/10.17718/tojde.306561

Johnson, D., Deterding, S., Kuhn, K.-A., Staneva, A., Stoyanov, S., \& Hides, L. (2016). Gamification for health and wellbeing: A systematic review of the literature. Internet Interventions, 6, 89-106. https://doi.org/10.1016/j.invent.2016.10.002

Kahu, E. R. (2013). Framing student engagement in higher education. Studies in Higher Education, 38(5), 758-773. https://doi.org/10.1080/03075079.2011.598505

Kapp, K. M. (2012a). Games, gamification, and the quest for learner engagement. T and D, 66(6), 64-68. Retrieved from

https://www.scopus.com/inward/record.uri?eid=2-s2.0$84862892253 \&$ partnerID $=40 \&$ md5=3d5cd4a19949a11159e3e4ba67557dfe

Kapp, K. M. (2012b). The gamification of learning and instruction: Game-based methods and strategies for training and education. San Francisco, CA: John Wiley \& Sons.

Kétyi, A. (2016, September). From mobile language learning to gamification: An overlook of research results with business management students over a five-year period. Porta Linguarum, 45-59. Retrieved from https://www.ugr.es/ portalin/articulos/PL_monograph1_2016/art_4.pdf

Khaleel, F. L., Ashaari, N. S., Wook, T. S. M. T., \& Ismail, A. (2016). Gamification elements for learning applications. International Journal on Advanced Science, Engineering and Information Technology, 6(6), 868-874. https://doi.org/10.18517/ijaseit.6.6.1379

Kirillov, A. V, Vinichenko, M. V, Melnichuk, A. V, Melnichuk, Y. A., \& Vinogradova, M. V. (2016). Improvement in the learning environment through gamification of the educational process. International Electronic Journal of Mathematics Education, 11(7), 2071-2085. Retrieved from https://www.iejme.com/download/improvement-inthe-learning-environment-through-gamification-of-the-educational-process.pdf

Kitchenham, B., Brereton, O. P., Budgen, D., Turner, M., Bailey, J., \& Linkman, S. (2009). Systematic literature reviews in software engineering - A systematic literature review. Information and Software Technology, 51(1), 7-15. https://doi.org/10.1016/j.infsof.2008.09.009

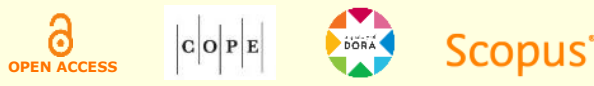


Klopfer, E., Osterweil, S., \& Salen, K. (2009). Moving learning games forward. Cambridge, MA: The Education Arcade. Koivisto, J., \& Hamari, J. (2014). Demographic differences in perceived benefits from gamification. Computers IN Human Behavior, 35, 179-188. https://doi.org/10.1016/j.chb.2014.03.007

Kolb, A. Y., \& Kolb, D. A. (2005). Learning styles and learning spaces: Enhancing experiential learning in higher education. Academy of Management Learning $\mathscr{F}$ Education, 4(2), 193-212. https://doi.org/10.5465/amle.2005.17268566

Kopcha, T. J., Ding, L., Neumann, K. L., \& Choi, I. (2016). Teaching technology integration to K-12 educators: A 'gamified' approach. TechTrends, 60(1), 62-69. https://doi.org/10.1007/s11528-015-0018-z

Krom, C. L. (2012). Using farmville in an introductory managerial accounting course to engage students, enhance comprehension, and develop social networking skills. Journal of Management Education, 36(6), 848-865. https://doi.org/10.1177/1052562912459029

Kuh, G. D., Kinzie, J., Schuh, J. H., \& Whitt, E. J. (2011). Student success in college: Creating conditions that matter. San Francisco, CA: John Wiley \& Sons.

Kumari, S. (2019). Gamification: An employee engagement strategy for organizations of 21st century. In N. Sharma, N. Chaudhary, \& V. K. Singh (Eds.), Management techniques for employee engagement in contemporary organizations (pp. 199-217). Hershey, PA: IGI Global.

Kuo, M. S., \& Chuang, T. Y. (2016). How gamification motivates visits and engagement for online academic dissemination - An empirical study. Computers in Human Behavior, 55(A), 16-27. https://doi.org/10.1016/j.chb.2015.08.025

Landers, R. N. (2014). Developing a theory of gamified learning: linking serious games and gamification of learning. Simulation and Gaming, 45(6), 752-768. https://doi.org/10.1177/1046878114563660

Landers, R. N., \& Armstrong, M. B. (2017). Enhancing instructional outcomes with gamification: An empirical test of the technology-enhanced training effectiveness model. Computers in Human Behavior, 71, 499-507. https://doi.org/10.1016/j.chb.2015.07.031

Landers, R. N., \& Callan, R. C. (2011). Casual social games as serious games: The psychology of gamification in undergraduate education and employee training. In M. Ma, A. Oikonomou, \& L. C. Jain (Eds.), Serious games and edutainment applications (pp. 399-423). London, UK: Springer-Verlag London.

Landers, R. N., \& Landers, A. K. (2014). An empirical test of the theory of gamified learning: The effect of leaderboards on time-on-task and academic performance. Simulation and Gaming, 45(6), $769-785$. https://doi.org/10.1177/1046878114563662

Langstrand, J., Cronemyr, P., \& Poksinska, B. (2015). Practise what you preach: quality of education in education on quality. Total Quality Management $\mathcal{F}$ Business Excellence, 26(11-12), 1202-1212. https://doi.org/10.1080/14783363.2014.925290

LaPiere, R. T. (1934). Attitudes vs. actions. Social Forces, 13(2), 230-237. https://doi.org/10.2307/2570339

Laskowski, M., \& Wojdyga, A. (2014). What can gamified university classroom teach us? Advanced Science Letters, 20(2), 402-405. https://doi.org/10.1166/asl.2014.5320

Leaning, M. (2015). A study of the use of games and gamification to enhance student engagement, experience and achievement on a theory-based course of an undergraduate media degree. Journal of Media Practice, $16(2), 155$. 170. https://doi.org/10.1080/14682753.2015.1041807

Lee, J., \& Hammer, J. (2011). Gamification in education: What, how, why bother? Academic Exchange Quarterly, 15(2), 146-151.

Lepper, M. R., Greene, D., \& Nisbett, R. E. (1973). Undermining children's intrinsic interest with extrinsic reward: A test of the" overjustification" hypothesis. Joumal of Personality and Social Psychology, 28(1), 129-137. https://doi.org/10.1037/h0035519

Libbey, H. P. (2004). Measuring student relationships to school: Attachment, bonding, connectedness, and engagement. Journal of School Health, 74(7), 274-283. https://doi.org/10.1111/j.1746-1561.2004.tb08284.x 
Li, C., Dong, Z., Untch, R. H., \& Chasteen, M. (2013). Engaging computer science students through gamification in an online social network based collaborative learning environment. International Journal of Information and Education Technology, 3(1), 72-77. https://doi.org/10.7763/ijiet.2013.v3.237

Lin, C.-P., \& Bhattacherjee, A. (2008). Elucidating individual intention to use interactive information technologies: The role of network externalities. International Journal of Electronic Commerce, 13(1), 85-108. https://doi.org/10.2753/jec1086-4415130103

Linehan, C., Kirman, B., Lawson, S., \& Chan, G. (2011, April). Practical, appropriate, empirically-validated guidelines for designing educational games. Proceedings of the SIGCHI Conference on Human Factors in Computing Systems, Boston, MA, USA

Li, W., Grossman, T., \& Fitzmaurice, G. (2012, October). GamiCAD: A gamified tutorial system for first time autocad users. Proceedings of the Annual ACM Symposium on User Interface Software and Technology, Cambridge, MA, 25. https://doi.org/10.1145/2380116.2380131

Maehr, M. L., \& Meyer, H. A. (1997). Understanding motivation and schooling: Where we've been, where we are, and where we need to go. Educational Psychology Review, 9(4), 371-409. https://doi.org/10.1023/A:1024750807365

Malas, R. I., \& Hamtini, T. M. (2016). A gamified e-learning design model to promote and improve learning. International Review on Computers and Software, 11(1), 8-19. https://doi.org/10.15866/irecos.v11i1.7913

Manrique-Losada, B., Gasca-Hurtado, G. P., \& Álvarez, M. C. G. (2015). Assessment proposal of teaching and learning strategies in software process improvement. Revista de La Facultad de Ingenieria, 77, 105-114. https://doi.org/10.17533/udea.redin.n77a13

Marks, R. B. (2000). Determinants of student evaluations of global measures of instructor and course value. Journal of Marketing Education, 22(2), 108-119. https://doi.org/10.1177/0273475300222005

Martí-Parreño, J., Méndez-Ibáñez, E., \& Alonso-Arroyo, A. (2016). The use of gamification in education: A bibliometric and text mining analysis. Joumal of Computer Assisted Learning, 32(6), 663-676. https://doi.org/10.1111/jcal.12161

Mayer, R. E. (2003). The promise of multimedia learning: using the same instructional design methods across different media. Learning and Instruction, 13(2), 125-139. https://doi.org/10.1016/s0959-4752(02)00016-6

McDaniel, R., \& Fanfarelli, J. (2016). Building better digital badges: Pairing completion logic with psychological factors. Simulation and Gaming, 47(1), 73-102. https://doi.org/10.1177/1046878115627138

McDaniel, R., Lindgren, R., \& Friskics, J. (2012, October). Using badges for shaping interactions in online learning environments. 2012 IEEE International Professional Communication Conference, Orlando, FL. https://doi.org/10.1109/IPCC.2012.6408619

McGonigal, J. (2011). Reality is broken: Why games make us better and how they can change the world. New York, NY: Penguin Press.

Mekler, E. D., Brithlmann, F., Tuch, A. N., \& Opwis, K. (2017). Towards understanding the effects of individual gamification elements on intrinsic motivation and performance. Computers in Human Behavior, 71, 525-534. https://doi.org/10.1016/j.chb.2015.08.048

Mladenovic, S., Krpan, D., \& Mladenovic, M. (2016). Using games to help novices embrace programming: From elementary to higher education. International Journal of Engineering Education, 32(1, B, SI), 521-531.

Moccozet, L., Tardy, C., Opprecht, W., \& Léonard, M. (2013, September). Gamification-based assessment of group work. ICL 2013 - International Conference on Interactive Collaborative Learning, Kazan, Russia. https://doi.org/10.1109/icl.2013.6644565

Moncada, S. M., \& Moncada, T. P. (2014). Gamification of learning in accounting education. Journal of Higher Education Theory and Practice, 14(3), 9-19.

Morillas Barrio, C., Munoz-Organero, M., \& Sanchez Soriano, J. (2016). Can gamification improve the benefits of student response systems in learning? An experimental study. IEEE Transactions on Emerging Topics in Computing, 4(3, SI), 429-438. https://doi.org/10.1109/TETC.2015.2497459

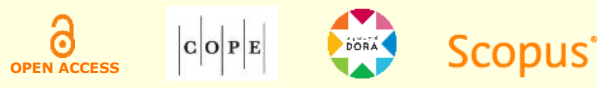


Müller, B. C., Reise, C., \& Seliger, G. (2015). Gamification in factory management education-a case study with Lego Mindstorms. Procedia CIRP, 26, 121-126. https://doi.org/10.1016/j.procir.2014.07.056

Muntean, C. I. (2011, October). Raising engagement in e-learning through gamification. Proceedings of International Conference on Virtual Learning ICVL, Cluj-Napoca, Romania, 6.

Murphy, E. A. (2005). Enhancing student learning with governmental accounting Jeopardy! Journal of Public Budgeting, Accounting EF Financial Management, 17(2), 223-248. https://doi.org/10.1108/jpbafm-17-02-2005-b007

Nah, F. F. H., Zeng, Q., Telaprolu, V. R., Ayyappa, A. P., \& Eschenbrenner, B. (2014). Gamification of education: A review of literature. Lecture Notes in Computer Science (Including Subseries Lecture Notes in Artificial Intelligence and Lecture Notes in Bioinformatics). https://doi.org/10.1007/978-3-319-07293-7_39

Nebel, S., Beege, M., Schneider, S., \& Rey, G. D. (2016). The higher the score, the higher the learning outcome? Heterogeneous impacts of leaderboards and choice within educational videogames. Computers in Human Behavior, 65, 391-401. https://doi.org/10.1016/j.chb.2016.08.042

Osipov, I. V, Nikulchev, E., Volinsky, A. A., \& Prasikova, A. Y. (2015). Study of gamification effectiveness in online e-learning systems. International Journal of Advanced Computer Science and Applications, 6(2), 71-77. https://doi.org/10.14569/ijacsa.2015.060211

Palomo-Duarte, M., Berns, A., Cejas, A., Dodero, J. M., Caballero, J. A., \& Ruiz-Rube, I. (2016). Assessing foreign language learning through mobile game-based learning environments. International Journal of Human Capital and Information Technology Professionals (IJHCITP), 7(2), 53-67. https://doi.org/10.4018/ijhcitp.2016040104

Paswan, A. K., \& Young, J. A. (2002). Student evaluation of instructor: A nomological investigation using structural equation modeling. Journal of Marketing Education, 24(3), 193-202. https://doi.org/10.1177/0273475302238042

Patel, M. M., Widdowson, M.-A., Glass, R. I., Akazawa, K., Vinjé, J., \& Parashar, U. D. (2008). Systematic literature review of role of noroviruses in sporadic gastroenteritis. Emerging Infectious Diseases, 14(8), 1224-1231. https://doi.org/10.3201/eid1408.071114

Pechenkina, E., Laurence, D., Oates, G., Eldridge, D., \& Hunter, D. (2017). Using a gamified mobile app to increase student engagement, retention and academic achievement. International Journal of Educational Technology in Higher Education, 14(1), 1-12. https://doi.org/10.1186/s41239-017-0069-7

Pedersen, M. K., Skyum, B., Heck, R., Muller, R., Bason, M., Lieberoth, A., \& Sherson, J. F. (2016). Virtual learning environment for interactive engagement with advanced quantum mechanics. Physical Review Physics Education Research, 12(1), 013102. https://doi.org/10.1103/PhysRevPhysEducRes.12.013102

Perryer, C., Celestine, N. A., Scott-Ladd, B., \& Leighton, C. (2016). Enhancing workplace motivation through gamification: Transferrable lessons from pedagogy. International Journal of Management Education, 14(3), 327-335. https://doi.org/10.1016/j.ijme.2016.07.001

Pe-Than, E. P. P., Goh, D. H.-L., \& Lee, C. S. (2015). Why do people play human computation games? Effects of perceived enjoyment and perceived output quality. Aslib Journal of Information Management, 67(5), $592-612$. https://doi.org/10.1108/ajim-03-2015-0037

Podsakoff, P. M., Mackenzie, S. B., Bachrach, D. G., \& Podsakoff, N. P. (2005). The influence of management journals in the 1980s and 1990s. Strategic Management Journal, 26(5), 473-488. https://doi.org/10.1002/smj.454

Poskitt, J., \& Gibbs, R. (2010). Student engagement in the middle years of schooling (year 7-10): A literature review. New Zealand: Ministry of Education.

Pritchard, A. (2013). Ways of learning: Learning theories and learning styles in the classroom. Abingdon, UK: Routledge.

Procci, K., Singer, A. R., Levy, K. R., \& Bowers, C. (2012). Measuring the flow experience of gamers: An evaluation of the DFS-2. Computers in Human Behavior, 28(6), 2306-2312. https://doi.org/10.1016/j.chb.2012.06.039

Riley, R. A., Cadotte, E. R., Bonney, L., \& MacGuire, C. (2013). Using a business simulation to enhance accounting education. Issues in Accounting Education, 28(4), 801-822. https://doi.org/10.2308/iace-50512

Rust, C., Price, M., \& O’Donovan, B. (2003). Improving students' learning by developing their understanding of assessment criteria and processes. Assessment $\mathcal{E}$ Evaluation in Higher Education, 28(2), 147-164. https://doi.org/10.1080/02602930301671

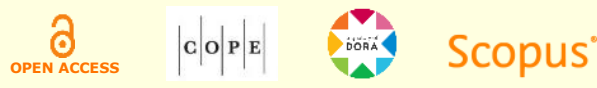


Ryan, R. M., \& Deci, E. L. (2000a). Intrinsic and extrinsic motivations: Classic definitions and new directions. Contemporary Educational Psychology, 25(1), 54-67. https://doi.org/10.1006/ceps.1999.1020

Ryan, R. M., \& Deci, E. L. (2000b). Self-determination theory and the facilitation of intrinsic motivation, social development, and well-being. American Psychologist, 55(1), 68-78. https://doi.org/10.1037//0003-066x.55.1.68

Ryan, R. M., Rigby, C. S., \& Przybylski, A. (2006). The motivational pull of video games: A self-determination theory approach. Motivation and Emotion, 30(4), 344-360. https://doi.org/10.1007/s11031-006-9051-8

Sabourin, J. L., \& Lester, J. C. (2014). Affect and engagement in game-basedlearning environments. IEEE Transactions on Affective Computing, 5(1), 45-56. https://doi.org/10.1109/t-affc.2013.27

Saeed, S., \& Zyngier, D. (2012). How motivation influences student engagement: A qualitative case study. Journal of Education and Learning, 1(2), 252-267. https://doi.org/10.5539/jel.v1n2p252

Sailer, M., Hense, J. U., Mayr, S. K., \& Mandl, H. (2017). How gamification motivates: An experimental study of the effects of specific game design elements on psychological need satisfaction. Computers in Human Behavior, 69, 371-380. https://doi.org/10.1016/j.chb.2016.12.033

Sardi, L., Idri, A., \& Fernández-Alemán, J. L. (2017). A systematic review of gamification in e-Health. Journal of Biomedical Informatics, 71, 31-48. https://doi.org/10.1016/j.jbi.2017.05.011

Schoech, D., Boyas, J. F., Black, B. M., \& Elias-Lambert, N. (2013). Gamification for behavior change: lessons from developing a social, multiuser, web-tablet based prevention game for youths. Journal of Technology in Human Services, 31(3), 197-217. https://doi.org/10.1080/15228835.2013.812512

Schuler, R. S., \& Jackson, S. E. (1987). Linking competitive strategies with human resource management practices. The Academy of Management Executive, 1(3), 207-219. Retrieved from https://www.jstor.org/stable/4164753

Seixas, L. da R., Gomes, A. S., \& Melo, I. J. de, Filho. (2016). Effectiveness of gamification in the engagement of students. Computers in Human Behavior, 58, 48-63. https://doi.org/10.1016/j.chb.2015.11.021

Sendaug, S., \& Odabacsi, H. F. (2009). Effects of an online problem based learning course on content knowledge acquisition and critical thinking skills. Computers $\mathscr{E}$ Education, 53(1), $132-141$. https://doi.org/10.1016/j.compedu.2009.01.008

Shernoff, E. S., Kratochwill, T. R., \& Stoiber, K. C. (2003). Training in evidence-based interventions (EBIs): What are school psychology programs teaching? Journal of School Psychology, 41(6), 467-483. https://doi.org/10.1016/j.jsp.2003.07.002

Silins, H., \& Mulford, B. (2004). Schools as learning organisations - Effects on teacher leadership and student outcomes. School Effectiveness and School Improvement, 15(3-4), 443-466. https://doi.org/10.1080/09243450512331383272

Simões, J., Redondo, R. D., \& Vilas, A. F. (2013). A social gamification framework for a K-6 learning platform. Computers in Human Behavior, 29(2), 345-353. https://doi.org/10.1016/j.chb.2012.06.007

Sousa-Vieira, M. E., Lopez-Ardao, J. C., Fernandez-Veiga, M., Rodriguez-Perez, M., \& Lopez-Garcia, C. (2015). Using social learning methodologies in higher education. International Journal of Engineering Pedagogy, 5(2), 64-72. https://doi.org/10.3991/ijep.v5i2.4645

Stott, A., \& Neustaedter, C. (2013). Analysis of gamification in education. Retrieved from http://clab.iat.sfu.ca/pubs/Stott-Gamification.pdf

Strmečki, D., Bernik, A., \& Radošević, D. (2015). Gamification in e-learning: Introducing gamified design elements into e-learning systems. Journal of Computer Science, 11(12), 1108-1117. https://doi.org/10.3844/jcssp.2015.1108.1117

Su, C.-H., \& Cheng, C.-H. (2015). A mobile gamification learning system for improving the learning motivation and achievements. Journal of Computer Assisted Leaming, 31(3), 268-286. https://doi.org/10.1111/jcal.12088

Su, C.-H., \& Cheng, C.-H. (2016). Developing and evaluating creativity gamification rehabilitation system: The application of PCA-ANFIS based emotions model. Eurasia Journal of Mathematics Science and Technology Education, 12(5), 1443-1468. https://doi.org/10.12973/eurasia.2016.1527a

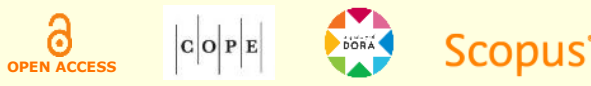


Surendeleg, G., Murwa, V., Yun, H.-K., \& Kim, Y. S. (2014). The role of gamification in education - A literature review. Contemporary Engineering Sciences, 7(29-32), 1609-1616. https://doi.org/10.12988/ces.2014.411217

Tanner, M. M., \& Lindquist, T. M. (1998). Teaching resource using monopoly TM and teams-gamestournaments in accounting education: A cooperative learning teaching resource. Accounting Education, 7(2), 139-162. https://doi.org/10.1080/096392898331225

Tanner, J. R., Stewart, G., Totaro, M. W., \& Hargrave, M. (2012). Business simulation games: Effective teaching tools or window dressing? American Journal of Business Education (AJBE), 5(2), 115-128. https://doi.org/10.19030/ajbe.v5i2.6814

Tao, Y.-H., Cheng, C.-J., \& Sun, S.Y. (2009). What influences college students to continue using business simulation games? The Taiwan experience. Computers $\mathcal{G}$ Education, 53(3), 929-939. https://doi.org/10.1016/j.compedu.2009.05.009

Tranfield, D., Denyer, D., \& Smart, P. (2003). Towards a methodology for developing evidence-informed management knowledge by means of systematic review. British Journal of Management, 14(3), 207-222. https://doi.org/10.1111/1467-8551.00375

Trowler, V. (2010, November). Student engagement literature review. Heslington, UK: The Higher Education Academy.

Tynjälä, P. (1999). Towards expert knowledge? A comparison between a constructivist and a traditional learning environment in the university. International Journal of Educational Research, 31(5), 357-442. https://doi.org/10.1016/s0883-0355(99)00012-9

van Rosmalen, P., \& Westera, W. (2014). Introducing serious games with wikis: Empowering the teacher with simple technologies. Interactive Learning Environments, 22(5), 564-577. https://doi.org/10.1080/10494820.2012.707128

Venkatesh, V., Morris, M. G., \& Ackerman, P. L. (2000). A longitudinal field investigation of gender differences in individual technology adoption decision-making processes. Organizational Behavior and Human Decision Processes, 83(1), 33-60. https://doi.org/10.1006/obhd.2000.2896

Werbach, K., \& Hunter, D. (2012). For the win: How game thinking can revolutionize your business. Philadelphia, PA: Wharton Digital Press.

Whitehill, B. (1999). American games: A historical perspective. Board Game Studies, 2(1), 114-116.

Willemse, M., Lunenberg, M., \& Korthagen, F. (2005). Values in education: A challenge for teacher educators. Teaching and Teacher Education, 21(2), 205-217. https://doi.org/10.1016/j.tate.2004.12.009

Williams, D., Yee, N., \& Caplan, S. E. (2008). Who plays, how much, and why? Debunking the stereotypical gamer profile. Journal of Computer-Mediated Communication, 13(4), 993-1018. https://doi.org/10.1111/j.1083. 6101.2008.00428.x

Witt, J. K. (2011). Action's effect on perception. Current Directions in Psychological Science, 20(3), 201-206. https://doi.org/10.1177/0963721411408770

Wu, M. (2011). Gamification 101: The psychology of motivation [Lithium Community]. Retrieved from https://community.khoros.com/t5/Science-of-Social-Blog/Gamification-101-The-Psychology-of-Motivation/ba$\mathrm{p} / 21864$

Xu, F., Buhalis, D., \& Weber, J. (2017). Serious games and the gamification of tourism. Tourism Management, 60, 244-256. https://doi.org/10.1016/j.tourman.2016.11.020

Xu, H., Song, D., Yu, T., \& Tavares, A. (2017). An enjoyable learning experience in personalising learning based on knowledge management: A case study. Eurasia Journal of Mathematics Science and Technology Education, 13(7), 3001. 3018. https://doi.org/10.12973/eurasia.2017.00702a

Yalabik, B., Howard, M., \& Roden, S. (2012). The innovation game: Lessons in strategy and managing operations. International Journal of Operations $\mathcal{E}$ Production Management, 32(12), 1441-1459. https://doi.org/10.1108/01443571211284188

Yildiz, S. M. (2014). Service quality evaluation in the school of physical education and sports: An empirical investigation of students' perceptions. Total Quality Management $\mathcal{E}$ Business Excellence, 25(1-2), 80-94. https://doi.org/10.1080/14783363.2011.637804

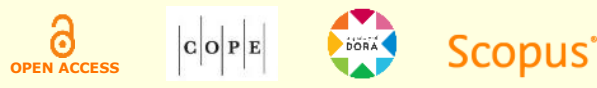


Young, M. R., Klemz, B. R., \& Murphy, J. W. (2003). Enhancing learning outcomes: The effects of instructional technology, learning styles, instructional methods, and student behavior. Joumal of Marketing Education, 25(2), 130-142. https://doi.org/10.1177/0273475303254004

Zamora, J. C. F., \& Aranda, D. A. (2017). Implementation of a gamification platform in a master degree (Master in Economics). Working Papers on Operations Management, 8, 181-190. https://doi.org/10.4995/wpom.v8i0.7431

Zichermann, G., \& Cunningham, C. (2011). Gamification by design: Implementing game mechanics in Web and mobile apps. Sebastopol, CAN: O’Reilly Media.

\section{Author contributions}

$1^{\text {st }}$ author: data curation, formal analysis, investigation, methodology, writing-original draft, conclusions, writingreview and editing.

$2^{\text {nd }}$ author: conclusions, writing-review and editing.

$3^{\text {rd }}$ author: conclusions, writing-review and editing.

\section{Authors}

Rui Jorge Rodrigues da Silva

Universidade de Trás-os-Montes e Alto Douro, Escola de Ciências Humanas e Sociais, CETRAD - Centre for Transdisciplinary Development Studies

Edifício do Pólo I da ECHS, Quinta dos Prados, 5000-801, Vila Real, Portugal

ruisilva@utad.pt

iD https://orcid.org/0000-0002-0283-9462

\section{Ricardo Gouveia Rodrigues}

Universidade da Beira Interior, NECE - Research Center in Business Sciences

Rua Marquês de Ávila e Bolama, 6201-001, Covilhã, Portugal

rgrodrigues@ubi.pt

iD https://orcid.org/0000-0001-6382-5147

\section{Carmem Teresa Pereira Leal}

Universidade de Trás-os-Montes e Alto Douro, Escola de Ciências Humanas e Sociais, CETRAD - Centre for Transdisciplinary Development Studies

Edifício do Pólo I da ECHS, Quinta dos Prados, 5000-801, Vila Real, Portugal

cleal@utad.pt

iD https://orcid.org/0000-0002-7860-9858 